Prepared in cooperation with the National Park Service

\title{
Geochemical Investigation of Source Water to Cave Springs, Great Basin National Park, White Pine County, Nevada
}

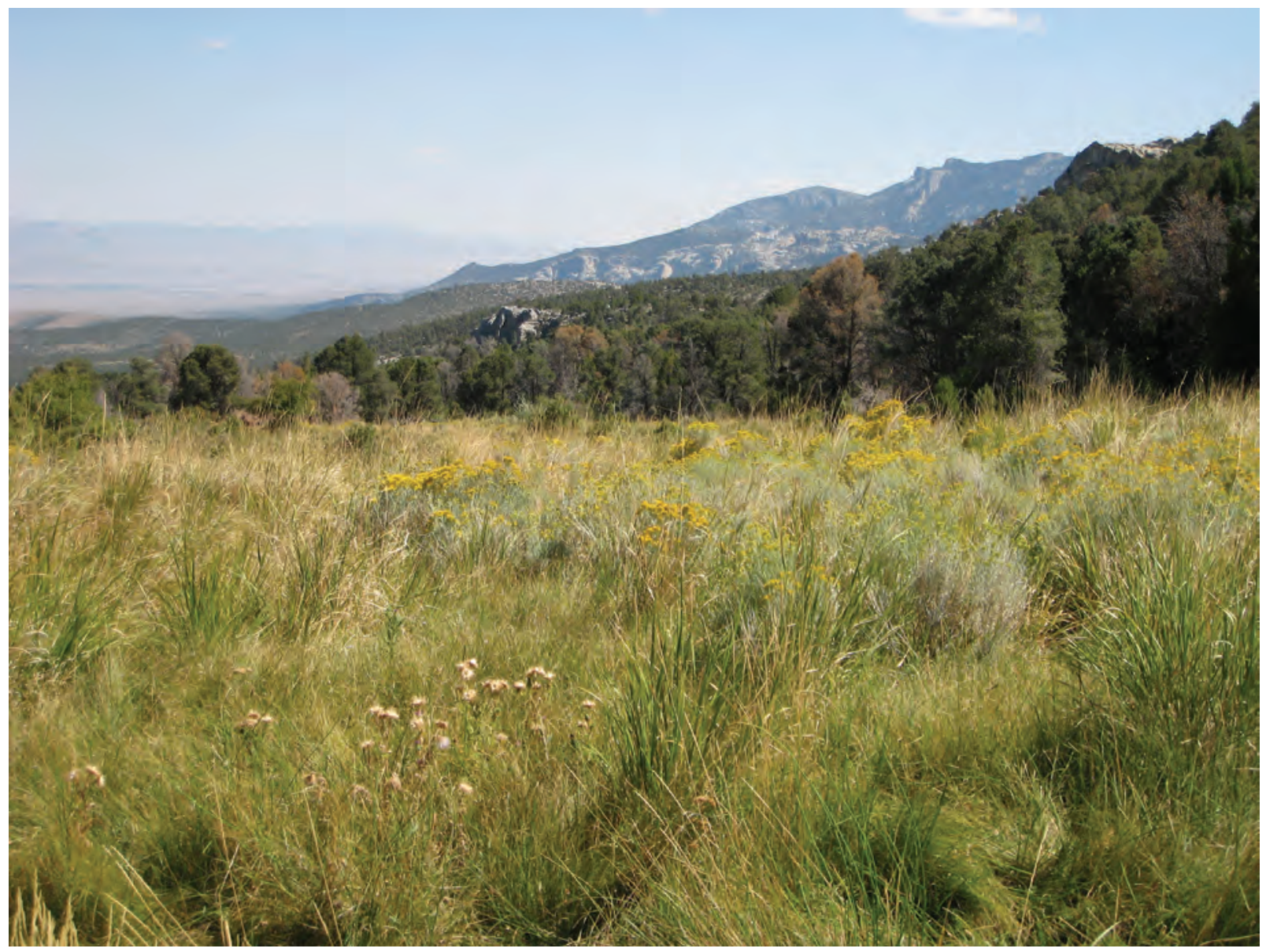

Scientific Investigations Report 2009-5073 
Cover: Cave Springs discharge area. View is southeast toward Garrison, Utah in Snake Valley. Nearest rock outcrop in center of photograph is middle Cambrian Pole Canyon Limestone. Nearest rock outcrop on right side of photograph above meadow is Tertiary granite. (Photograph taken by David E. Prudic, U.S. Geological Survey, September 7, 2007.) 


\section{Geochemical Investigation of Source Water to Cave Springs, Great Basin National Park, White Pine County, Nevada}

By David E. Prudic and Patrick A. Glancy

Prepared in cooperation with the National Park Service

Scientific Investigations Report 2009-5073 


\title{
U.S. Department of the Interior \\ KEN SALAZAR, Secretary \\ U.S. Geological Survey \\ Suzette M. Kimball, Acting Director
}

\section{U.S. Geological Survey, Reston, Virginia: 2009}

\author{
For more information on the USGS — the Federal source for science about the Earth, its natural and living resources, \\ natural hazards, and the environment, visit http://www.usgs.gov or call 1-888-ASK-USGS \\ For an overview of USGS information products, including maps, imagery, and publications, \\ visit http://www.usgs.gov/pubprod \\ To order this and other USGS information products, visit http://store.usgs.gov
}

\begin{abstract}
Any use of trade, product, or firm names is for descriptive purposes only and does not imply endorsement by the U.S. Government.

Although this report is in the public domain, permission must be secured from the individual copyright owners to reproduce any copyrighted materials contained within this report.
\end{abstract}

Suggested citation:

Prudic, D.E., and Glancy, P.A., 2009, Geochemical investigation of source water to Cave Springs, Great Basin National Park, White Pine County, Nevada: U.S. Geological Survey Scientific Investigations Report 2009-5073, 28 p. 


\section{Contents}

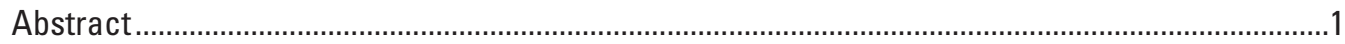

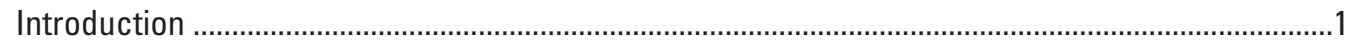

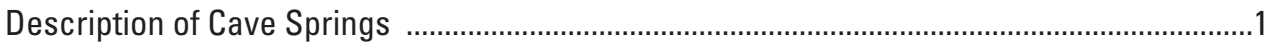

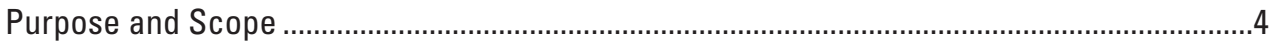

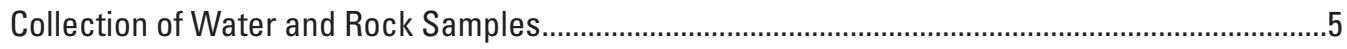

Location and Description of Sampling Sites ........................................................................5

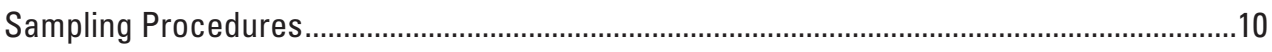

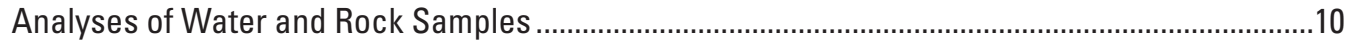

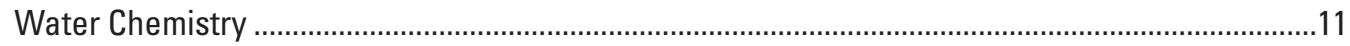

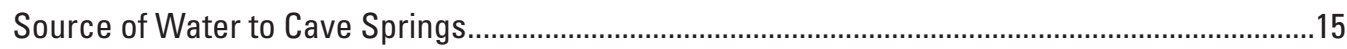

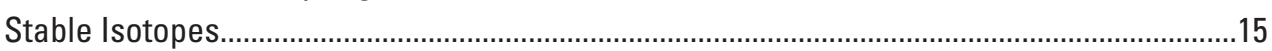

Source of Calcium, Bicarbonate, and Strontium at Cave Springs.............................................19

Modeling Water Chemistry at Cave Springs ................................................................................20

Estimated Mean Age of Water at Four Sampling Sites ....................................................................24

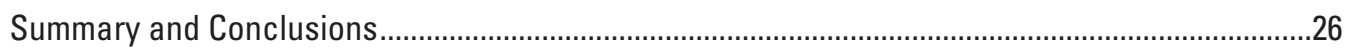

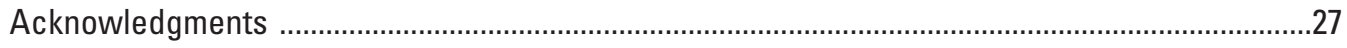

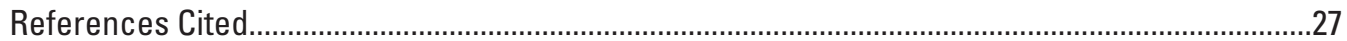




\section{Figures}

Figure 1. Map showing location of Great Basin National Park, White Pine County, Nevada, and precipitation gages used for collecting stable isotopes of hydrogen and oxygen

Figure 2. Map showing generalized geology near Cave Springs, location of Lehman Caves Visitor Center, Lehman Creek and Baker Creek campgrounds, Great Basin National Park, Nevada, and water and rock sampling sites

Figure 3. Cross sections showing two possible geologic profiles along Lehman Creek showing $(A)$ granite intrusion splitting Pole Canyon Limestone and $(B)$ granite replacement of Pioche Shale between Prospect Mountain Quartzite and Pole Canyon Limestone beneath alluvial and glacial deposits at Cave Springs, Great Basin National Park, Nevada ....

Figure 4. Photographs showing four water sampling sites at Cave Springs, permanent pool in Lehman Caves, and two nearby springs, Great Basin National Park, Nevada

Figure 5. Photographs showing three rock sampling sites near Cave Springs, Great Basin National Park, Nevada, September 8, 2007

Figure 6. Graph showing relation between specific conductance and dissolved solids in water sampled from Cave Springs, a permanent pool in Lehman Caves, and two nearby springs, Great Basin National Park, Nevada, September 2007

Figure 7. Diagram showing distribution of water chemistry from samples collected from Cave Springs, a permanent pool in Lehman Caves, and two nearby springs, Great Basin National Park, Nevada, September 2007

Figure 8. Graph showing deuterium and oxygen-18 in water samples collected September 2007 from Cave Springs, a permanent pool in Lehman Caves, and two nearby springs, Great Basin National Park, Nevada, in relation to precipitation collected from Cave Mountain, Connors Pass, and Mount Moriah in neighboring mountain ranges between April 1991 and June 1997

Figure 9. Graph showing relation between delta carbon-13 $\left(\delta^{13} \mathrm{C}\right)$ and dissolved inorganic carbon in water samples collected from Cave Springs, a permanent pool in Lehman Caves, and two nearby springs, Great Basin National Park, Nevada, September 2007

Figure 10. Graph showing relation between the ratio of strontium-87 to strontium-86 and strontium concentrations in water samples collected from Cave Springs, a permanent pool in Lehman Caves, and two nearby springs, and in rock samples of Pole Canyon Limestone, Tertiary granite, and Prospect Mountain Quartzite, Great Basin National Park, Nevada, September 2007 


\section{Tables}

Table 1. Location and elevation of water and rock sampling sites at Great Basin National Park, Nevada

Table 2. Selected constituents analyzed in water and rock samples collected near Cave Springs at Great Basin National Park, Nevada, and U.S. Geological Survey laboratories used for analysis

Table 3. Concentrations of selected dissolved constituents in water collected from Cave Springs, a permanent pool in Lehman Caves, and two nearby springs at Great Basin National Park, Nevada

Table 4. Concentrations of nutrients in water collected from Cave Springs, a permanent pool in Lehman Caves, and two nearby springs at Great Basin National Park, Nevada

Table 5. Stable isotopes of hydrogen, oxygen, carbon, and strontium in water collected from Cave Springs, a permanent pool in Lehman Caves, and two nearby springs at Great Basin National Park, Nevada

Table 6. Stable isotopes of oxygen and carbon in rock sample of Pole Canyon Limestone and ratio of strontium isotopes and concentration of strontium in rock samples of Pole Canyon Limestone, Tertiary granite, and Prospect Mountain Quartzite near Cave Springs at Great Basin National Park, Nevada ......

Table 7. Saturation indexes for selected minerals and the partial pressure of carbon dioxide gas calculated from dissolved chemistry in water from Cave Springs prior to and after reconstruction of water-collection system and from Marmot Spring, Great Basin National Park, Nevada

Table 8. Dissolved constituents and mineral and gas phases used to model geochemical reactions assuming initial waters from Cave Springs prior to reconstruction of water-collection system and Marmot Spring, and final water from Cave Springs after reconstruction, Great Basin National Park, Nevada

Table 9. Results of geochemical modeling using NETPATH to evaluate dissolution of carbonate rocks at Cave Springs assuming initial water is water from Cave Springs prior to reconstruction of water-collection system, Great Basin National Park, Nevada

Table 10. Results of geochemical modeling using NETPATH to evaluate dissolution of carbonate rocks at Cave Springs assuming initial water is water from Marmot Spring, Great Basin National Park, Nevada ....

Table 11. Concentrations of dissolved gases and chlorofluorocarbons in water collected from Cave Springs, a permanent pool in Lehman Caves, and two nearby springs, Great Basin National Park, Nevada

Table 12. Estimated recharge temperatures from dissolved gases and range in age from chlorofluorocarbon analyses of water sampled from Cave Springs, a permanent pool in Lehman Caves, and two nearby springs, Great Basin National Park, Nevada 


\section{Conversion Factors and Datums}

Conversion Factors

Inch/Pound to SI

\begin{tabular}{lll}
\hline \multicolumn{1}{c}{ Multiply } & By & \multicolumn{1}{c}{ To obtain } \\
\hline inch (in.) & Length & \\
foot (ft) & 25.40 & millimeter $(\mathrm{mm})$ \\
mile (mi) & 0.3048 & meter $(\mathrm{m})$ \\
& 1.609 & kilometer $(\mathrm{km})$ \\
\hline square mile $\left(\mathrm{mi}^{2}\right)$ & Area & \\
\hline & 2.59 & square kilometer $\left(\mathrm{km}^{2}\right)$ \\
\hline gallon $(\mathrm{gal})$ & Volume & \\
cubic foot $\left(\mathrm{ft}^{3}\right)$ & 3.785 & liter $(\mathrm{L})$ \\
& 0.02832 & cubic meter $\left(\mathrm{m}^{3}\right)$ \\
\hline cubic foot per second $\left(\mathrm{ft}^{3} / \mathrm{s}\right)$ & Flow rate & \\
\hline
\end{tabular}

Chemical concentrations, volumes of water, and mass of rocks collected for analyses are reported in SI units:

SI to Inch/Pound

\begin{tabular}{lcl}
\hline \multicolumn{1}{c}{ Multiply } & \multicolumn{1}{c}{ By obtain } \\
\hline cubic centimeter per liter $\left(\mathrm{cm}^{3} / \mathrm{L}\right)$ & \multicolumn{1}{c}{ Excess air concentration } & \\
\hline & Chemical concentration & \\
\hline milligram per kilogram $(\mathrm{mg} / \mathrm{kg})$ & 0.0070 & grain per pound $(\mathrm{gr} / \mathrm{lb})$ \\
milligram per liter $(\mathrm{mg} / \mathrm{L})$ & 0.05841 & grain, avoirdupois per gallon $(\mathrm{gr} / \mathrm{gal})$ \\
picogram per kilogram $(\mathrm{pg} / \mathrm{kg})$ & $7.0 \times 10^{-12}$ & grain per pound $(\mathrm{gr} / \mathrm{lb})$ \\
\hline & \multicolumn{1}{c}{ Volume } & \\
\hline cubic centimeter $\left(\mathrm{cm}^{3}\right)$ & 0.0610 & cubic inch (in $\left.{ }^{3}\right)$ \\
liter $(\mathrm{L})$ & 0.2642 & U.S. gallon (gal) \\
milliliter $(\mathrm{mL})$ & 0.001057 & quart (qt) \\
\hline & \multicolumn{1}{c}{ Mass } & \\
\hline picogram $(\mathrm{pg})$ & $1.543 \times 10^{-11}$ & grain, avoirdupois $(\mathrm{gr})$ \\
milligram $(\mathrm{mg})$ & 0.01543 & grain, avoirdupois $(\mathrm{gr})$ \\
gram $(\mathrm{g})$ & 0.03527 & ounce, avoirdupois $(\mathrm{oz})$ \\
kilogram $(\mathrm{kg})$ & 2.205 & pound, avoirdupois $(\mathrm{lb})$ \\
\hline & Flow rate & \\
\hline liter per minute $(\mathrm{L} / \mathrm{min})$ & 0.2642 & gallon per minute $(\mathrm{gal} / \mathrm{min})$ \\
\hline
\end{tabular}

Temperature in degrees Celsius $\left({ }^{\circ} \mathrm{C}\right)$ may be converted to degrees Fahrenheit $\left({ }^{\circ} \mathrm{F}\right)$ as follows:

$$
{ }^{\circ} \mathrm{F}=\left(1.8 x^{\circ} \mathrm{C}\right)+32 .
$$




\section{Conversion Factors and Datums-Continued}

Specific conductance is given in microsiemens per centimeter at 25 degrees Celsius $(\mu \mathrm{S} / \mathrm{cm}$ at $\left.25^{\circ} \mathrm{C}\right)$.

Concentration units for chemical constituents in water are milligrams of solute per liter of solution (mg/L).

Concentration units for dissolution of a mineral in water are millimoles of dissolved mineral per kilogram of water $(\mathrm{mmol} / \mathrm{kg})$.

Concentration units for chemical constituents in rock are milligrams of constituent per kilogram of rock $(\mathrm{mg} / \mathrm{kg})$.

Concentration units for excess air dissolved in water are cubic centimeters per liter $\left(\mathrm{cm}^{3} / \mathrm{L}\right)$.

Concentration units for chlorofluorocarbon concentrations dissolved in water are picograms of chlorofluorocarbon per kilogram of water $(\mathrm{pg} / \mathrm{kg})$.

Datums

Vertical coordinate information is referenced to the North American Vertical Datum of 1929

(NAVD 29).

Horizontal coordinate information is referenced to North American Datum of 1983 (NAD 83).

Altitude, as used in this report, refers to distance above the vertical datum. 
This page intentionally left blank. 


\title{
Geochemical Investigation of Source Water to Cave Springs, Great Basin National Park, White Pine County, Nevada
}

\author{
By David E. Prudic and Patrick A. Glancy
}

\section{Abstract}

Cave Springs supply the water for the Lehman Caves Visitor Center at Great Basin National Park, which is about 60 miles east of Ely, Nevada, in White Pine County. The source of water to the springs was investigated to evaluate the potential depletion caused by ground-water pumping in areas east of the park and to consider means to protect the supply from contamination. Cave Springs are a collection of several small springs that discharge from alluvial and glacial deposits near the contact between quartzite and granite. Four of the largest springs are diverted into a water-collection system for the park. Water from Cave Springs had more dissolved strontium, calcium, and bicarbonate, and a heavier value of carbon-13 than water from Marmot Spring at the contact between quartzite and granite near Baker Creek campground indicating that limestone had dissolved into water at Cave Springs prior to discharging. The source of the limestone at Cave Springs was determined to be rounded gravels from a pit near Baker, Nevada, which was placed around the springs during the reconstruction of the water-collection system in 1996.

Isotopic compositions of water at Cave Springs and Marmot Spring indicate that the source of water to these springs primarily is from winter precipitation. Mixing of water at Cave Springs between alluvial and glacial deposits along Lehman Creek and water from quartzite is unlikely because deuterium and oxygen-18 values from a spring discharging from the alluvial and glacial deposits near upper Lehman Creek campground were heavier than the deuterium and oxygen-18 values from Cave Springs. Additionally, the estimated mean age of water determined from chlorofluorocarbon concentrations indicates water discharging from the spring near upper Lehman Creek campground is younger than that discharging from either Cave Springs or Marmot Spring. The source of water at Cave Springs is from quartzite and water discharges from the springs on the upstream side of the contact between quartzite and granite where the alluvial and glacial deposits are thin. Consequently, the potential for depletion of discharge at Cave Springs from ground-water pumping in Snake Valley east of the park is less than if the source of water was from alluvial and glacial deposits or carbonate rocks, which would be more directly connected to downstream pumping sites in Snake Valley.

\section{Introduction}

Great Basin National Park encompasses about $120 \mathrm{mi}^{2}$ of the highest parts of the southern Snake Range in eastern White Pine County, Nevada, near the border with Utah (fig. 1). The Southern Nevada Water Authority has applied for rights to withdraw large quantities of ground water from adjacent Spring Valley and Snake Valley. The National Park Service is concerned that pumping of ground water could adversely affect water resources of the park and in particular, the discharge of Cave Springs. Additionally, Cave Springs are near two popular camping areas and park managers are concerned about potential sources of contamination to the springs.

\section{Description of Cave Springs}

Cave Springs are in the Lehman Creek drainage about $1 \mathrm{mi}$ upstream of Lehman Caves and four of the larger springs are diverted at the source into a water-collection system that is used as the water supply for the Lehman Caves Visitor Center (fig. 2). The springs discharge from alluvial and glacial deposits near the contact between Proterozoic Prospect Mountain Quartzite and Tertiary granite (fig. 2). The granite west of Lehman Caves was called an aplitic granitoid rock by Lee and Van Loenen, 1971, p. 40. The discharge from Cave Springs is about $0.1 \mathrm{ft}^{3} / \mathrm{s}$ (Gretchen Baker, National Park Service, Great Basin National Park, written commun., 2004). A recently completed study (Elliott and others, 2006) indicated that the Lehman Creek drainage near and downstream of Cave Springs likely is susceptible to ground-water withdrawals farther downstream in Snake Valley because ground water in the alluvial and glacial deposits are connected with similar deposits in the valley. 


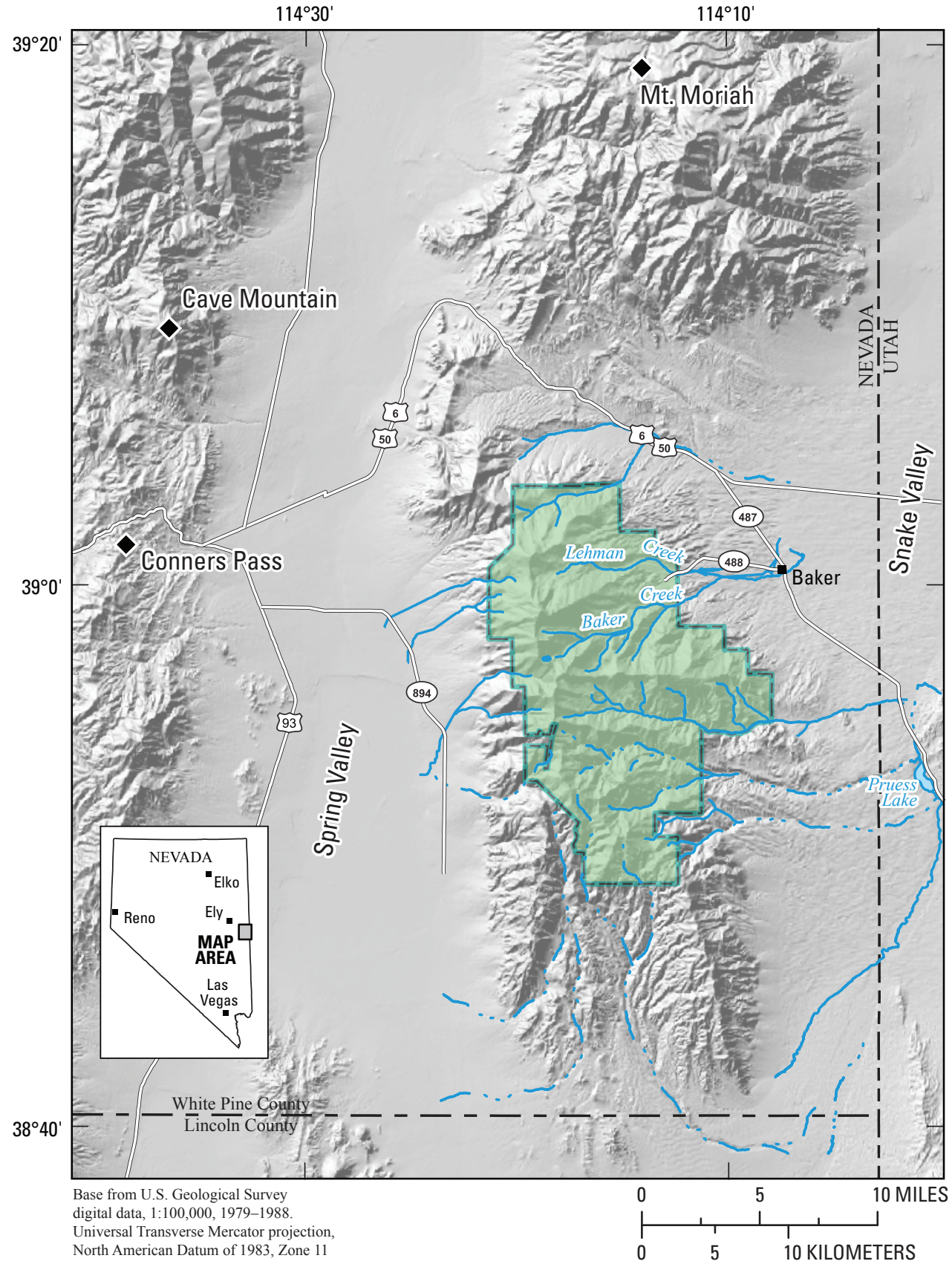

\section{EXPLANATION}

\section{$[-]$ Great Basin National Park $\diamond \quad$ Precipitation gage}

Figure 1. Location of Great Basin National Park, White Pine County, Nevada, and precipitation gages used for collecting stable isotopes of hydrogen and oxygen. Data from precipitation gages are from Friedman and others (2002). 


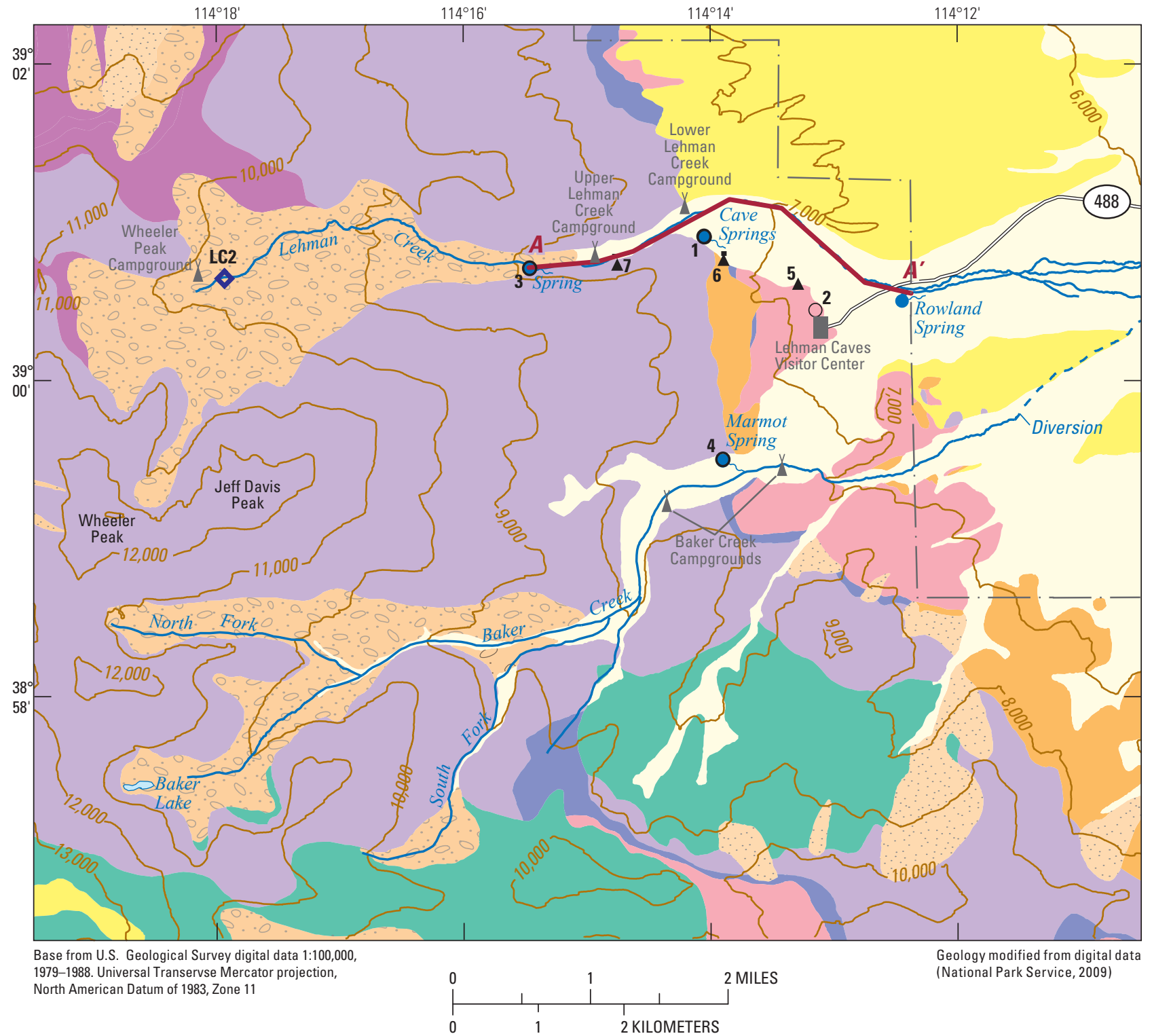

EXPLANATION

\section{Geology}

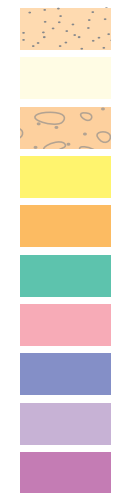

Qtl Talus and Landslide deposits

Qa Alluvium

Qg Glacial deposits

Qoa Older alluvium

Tgr Biotite granite

MZg Granite

€pc Pole Canyon Limestone, undifferentiated

Epi Pioche Shale

€Zpm Prospect Mountain Quartzite

\section{- . Great Basin National Park boundary}

Contour-Interval is 1,000 feet

A $\quad A^{\prime}$ Geologic profile shown in figure 3

o Spring

${ }^{4} \mathrm{O} \quad$ Water sampling site listed in table 1

5 Rock sampling site listed in table 1

LC2 Water sampling site (Acheampong, 1992)

Zm McCoy Creek Group, undifferentiated

Figure 2. Generalized geology near Cave Springs, location of Lehman Caves Visitor Center, Lehman Creek and Baker Creek campgrounds, Great Basin National Park, Nevada, and water and rock sampling sites. Geology modified from a digital geologic map available from the National Park Service (2009) that is based on 1:24,000 scale maps by Miller and the Stanford Geological Survey (2007). 
Discharge at Cave Springs could be shallow ground water from alluvial and glacial deposits associated with Lehman Creek, from Prospect Mountain Quartzite, from middle Cambrian Pole Canyon Limestone that might be buried beneath the alluvial and glacial deposits, or from a mixture of water flowing through these different formations (Elliott and others, 2006). The susceptibility of a decreasing discharge to Cave Springs due to ground-water pumping partly depends on the formations that provide water to the springs. If the water source is from alluvial and glacial deposits or Pole Canyon Limestone that are connected to alluvial deposits farther downstream, then drawdown of water levels from downstream pumping sites could propagate upstream and decrease the flow of Cave Springs. If the source of water was from Prospect Mountain Quartzite near the contact with the Tertiary granite, however, then drawdown of water levels from downstream pumping sites would not likely decrease flow of the springs because the granite would be an effective barrier that would restrict the upstream propagation of drawdown farther upstream. Furthermore, if the source of Cave Springs is from ground water in the shallow alluvial and glacial deposits, Great Basin National Park may need to expand their present fenced area to minimize contamination to the springs.

The Tertiary granite intruded and assimilated the Pioche Shale that separates the Prospect Mountain Quartzite from the Pole Canyon Limestone (Lee and Van Loenen, 1971, p. 40). Although the nearest outcrop of Pole Canyon Limestone is about 2,000 ft southeast of Cave Springs (fig. 2), the limestone might be present beneath the alluvial and glacial deposits at Cave Springs if the granite split the limestone as illustrated in figure 3. This concept was invoked by Elliott and others (2006, p. 33) because the specific conductance of Cave Springs during 2003 and 2004 was much greater than that in Lehman Creek and greater than the specific conductance from Marmot Spring (name of spring provided by Gretchen Baker, National Park Service, Great Basin National Park, written commun., 2008) at the contact between Prospect Mountain Quartzite and the Tertiary granite in the adjacent Baker Creek drainage (fig. 2). Conversely, if the limestone is absent beneath Cave Springs then the discharge from Cave Springs could be from the Prospect Mountain Quartzite at the contact with the Tertiary granite, and the higher specific conductance has some other cause.

\section{Purpose and Scope}

This report describes the geochemical investigation of Cave Springs to determine the source of water discharging from the springs and to determine if the water has been in contact with carbonate rocks. Water samples were collected in September 2007 from Cave Springs, a spring discharging from alluvial and glacial deposits near upper Lehman Creek campground, a permanent pool in Lehman Caves within

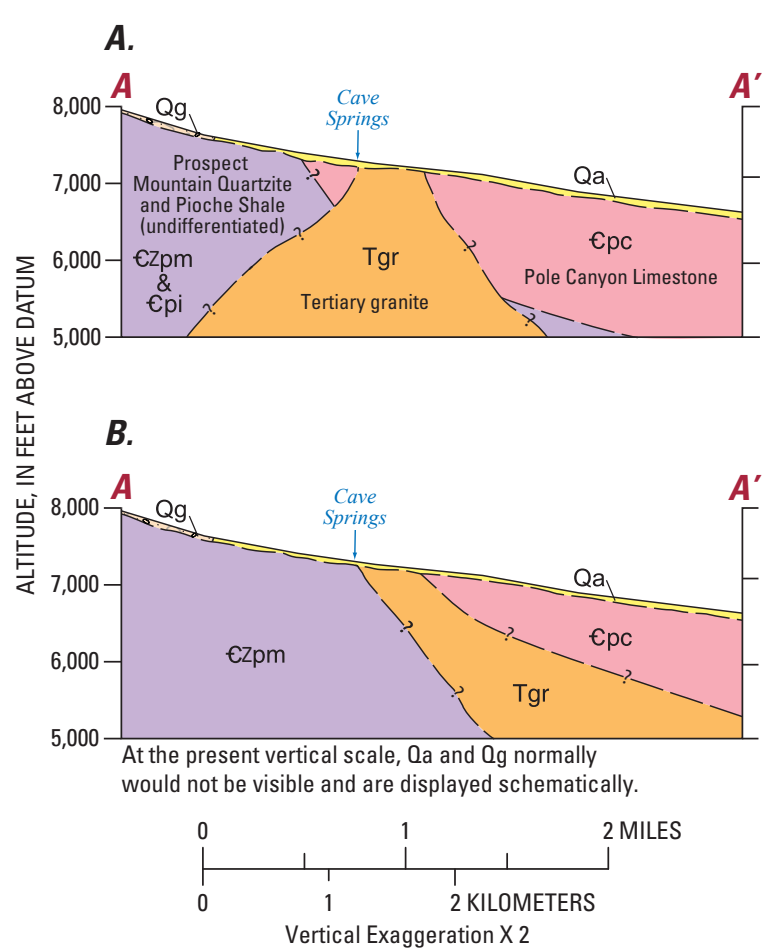

EXPLANATION

Geologic units described in figure 2

Contact-Approximately located, queried where existence or identity questionable

Figure 3. Two possible geologic profiles along Lehman Creek showing $(A)$ granite intrusion splitting Pole Canyon Limestone and $(B)$ granite replacement of Pioche Shale between Prospect Mountain Quartzite and Pole Canyon Limestone beneath alluvial and glacial deposits at Cave Springs, Great Basin National Park, Nevada. Cross section $A$ modified from Elliott and others, 2006 (fig. 18). Geologic profiles were drawn on the basis of geology by Hose and Blake (1976) and Miller and others (1995a and 1995b). Location of profile is shown in figure 2 .

the Middle Cambrian Pole Canyon Limestone, and Marmot Spring at the contact between Prospect Mountain Quartzite with Tertiary granite in the Baker Creek drainage (fig. 2). The samples were analyzed for major ions, selected trace elements, nutrients, stable isotopes (carbon, hydrogen, oxygen, and strontium), dissolved gases, and chlorofluorocarbons. Samples of Prospect Mountain Quartzite, Tertiary granite, and Pole Canyon Limestone were collected from outcrops near Cave Springs and analyzed for stable isotopes of strontium. The limestone also was analyzed for stable isotopes of carbon and oxygen. The source of water to Cave Springs was investigated by using the geochemical analyses of the water and rock samples and the geochemical models PHREEQC (Parkhurst, 1995; Parkhurst and Appelo, 1999) and NETPATH (Plummer and others, 1994; Parkhurst and Charlton, 2008). 


\section{Collection of Water and Rock Samples}

\section{Location and Description of Sampling Sites}

Cave Springs (site 1), a permanent pool in Lehman Caves (site 2), a spring near upper Lehman Creek campground that discharges from glacial deposits (site 3), and Marmot Spring in the Baker Creek drainage that discharges at the contact between Prospect Mountain Quartzite and Tertiary granite (site 4) were selected for sampling in this study (fig. 2). The permanent pool in Lehman Caves was selected to obtain a water sample that was only in contact with the Pole Canyon Limestone. The caves are in the outcrop area of the Pole Canyon Limestone (fig. 2) and deeper parts of the accessible area of the cave system near the permanent pool are dry, thus the only plausible source of water in the pool is infiltration of precipitation through the Pole Canyon Limestone. The spring near upper Lehman Creek campground discharges at the end of a terminal moraine and the water has the same specific conductance as water in adjacent Lehman Creek. The discharge of the spring was in excess of $1 \mathrm{ft}^{3} / \mathrm{s}$ when it was sampled, which doubled the flow in Lehman Creek. The volumetric flow rate was far too great and the temperature too cold for it to be ground-water flow through the Prospect Mountain Quartzite. Consequently, water discharging from the spring near upper Lehman Creek campground likely represents water from alluvial and glacial deposits upstream of Cave Springs, and water from the spring is a possible source of water to Cave Springs. Finally, the geology near Marmot Spring in the Baker Creek drainage is similar to that at Cave Springs (fig. 2).

Cave Springs was sampled at the overflow outlet of the water-collection system used to supply water to Lehman Caves Visitor Center (fig. 4A). The collection system at Cave Springs was rebuilt in 1996. A $1.5-\mathrm{ft}$ deep pool was excavated at the end of the overflow outlet. A permanent pool in Lehman Caves was sampled at the deepest part, which also was about $1.5 \mathrm{ft}$ deep (fig. $4 B$ ). Similar depth pools were excavated at the overflow outlet of the spring discharging from glacial deposits near upper Lehman Creek campground and from Marmot Spring (fig. $4 C$ and $4 D$ ).

Three rock samples were collected from outcrops between Lehman Caves Visitor Center and upper Lehman Creek campground (fig. 2). The first sample was of Pole Canyon Limestone collected from an outcrop on the south side of Lehman Creek drainage between Lehman Caves and Cave Springs (fig. 5A). The sample of Pole Canyon Limestone had been somewhat metamorphosed because of its proximity to the intruded granite. The second sample was of the Tertiary granite also collected from an outcrop on the south side of Lehman Creek drainage between where the Pole Canyon Limestone was collected and Cave Springs (fig. 5B). The third sample was of Prospect Mountain Quartzite. This sample was collected from outcrop on the south side of Lehman Creek drainage at the east end of the upper Lehman Creek campground (fig. 5C). Locations and land surface altitudes of water and rock sampling sites are summarized in table 1.

A. Site 1-Overflow outlet at Cave Springs, view is to west.

Figure 4. Four water sampling sites at Cave Springs, permanent pool in Lehman Caves, and two nearby springs, Great Basin National Park, Nevada. Site locations are shown in figure 2. 


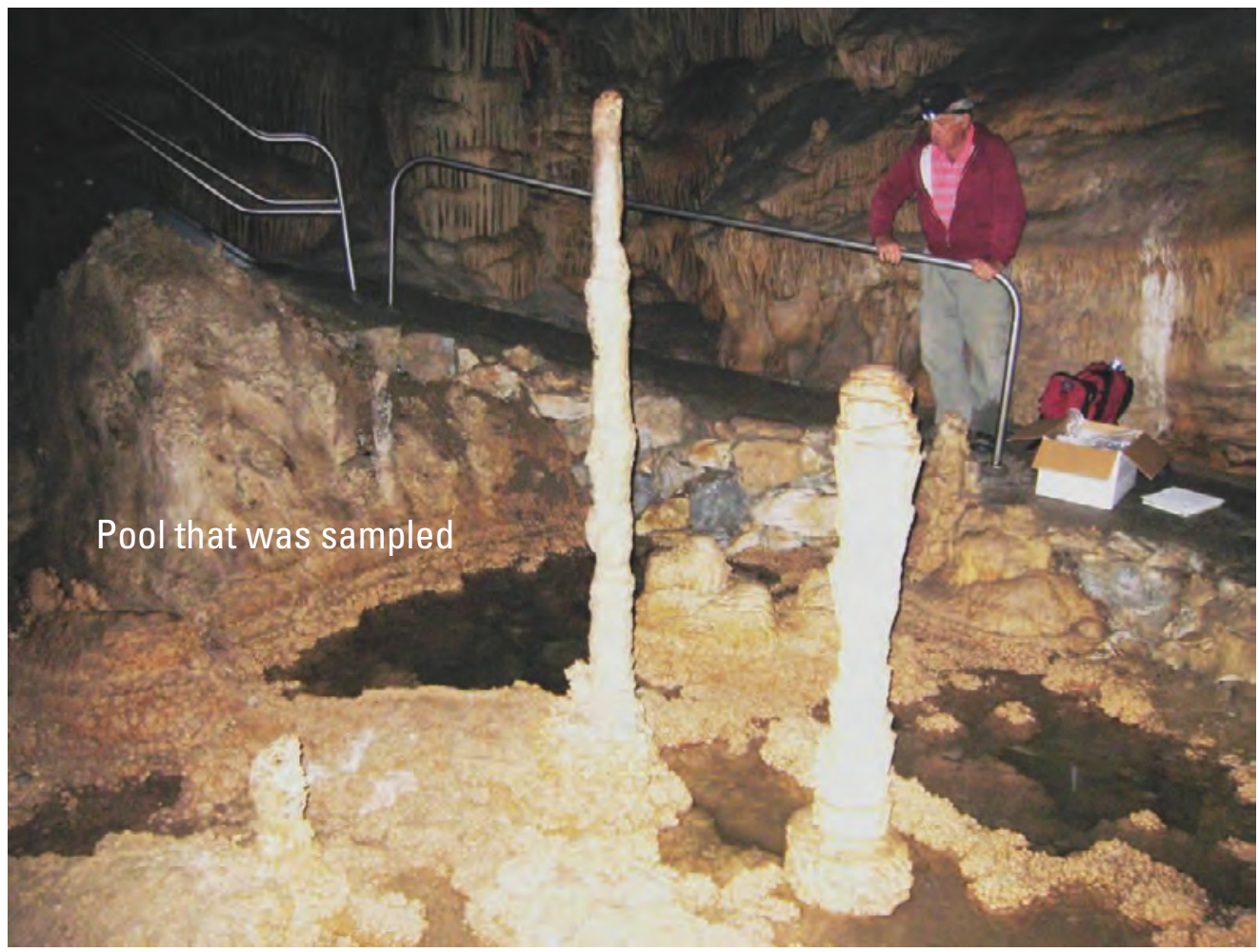

B. Site 2-Permanent pool in Lehman Caves.

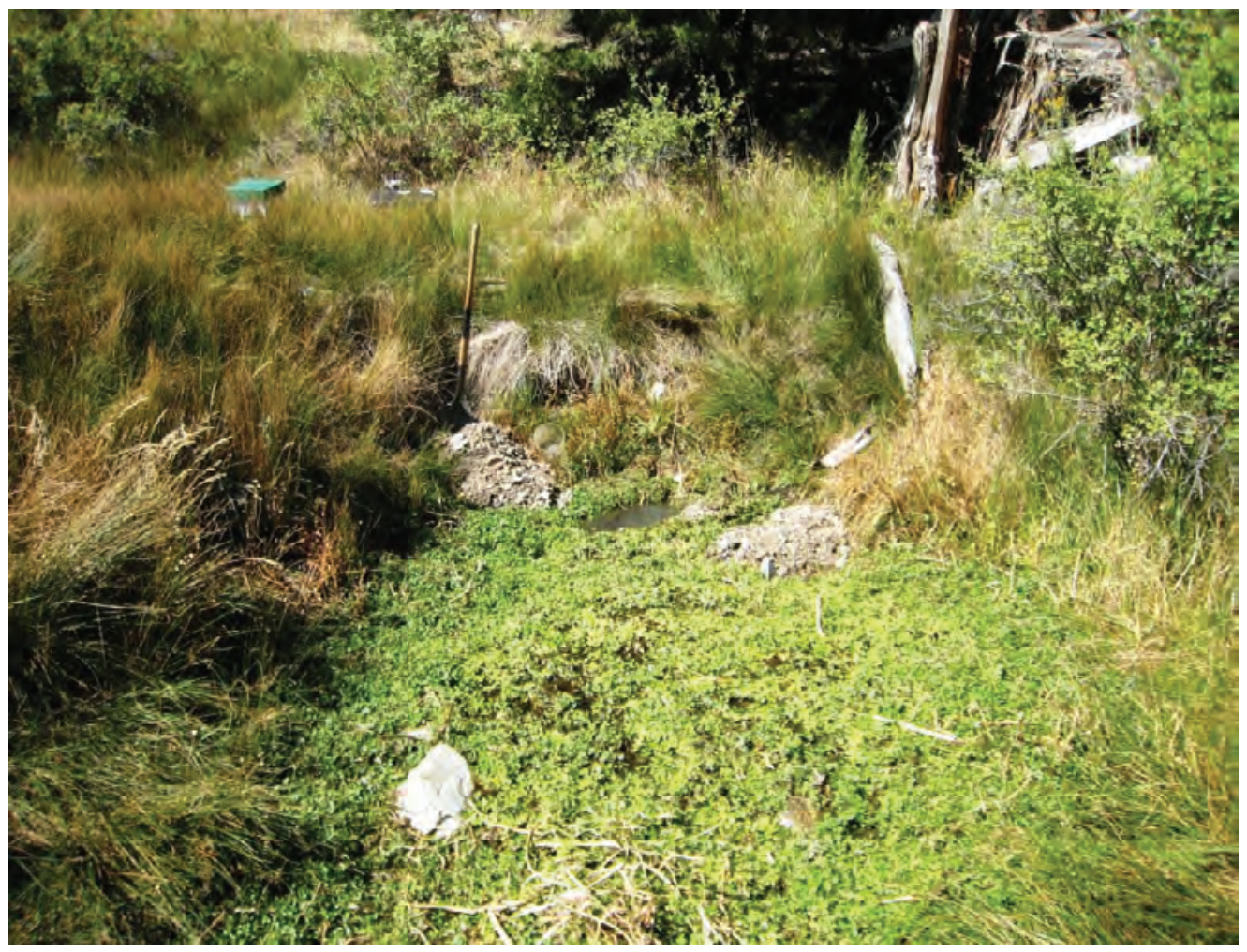

C. Site 3-Marmot Spring near Baker Creek campground, view is to north.

Figure 4.-Continued 


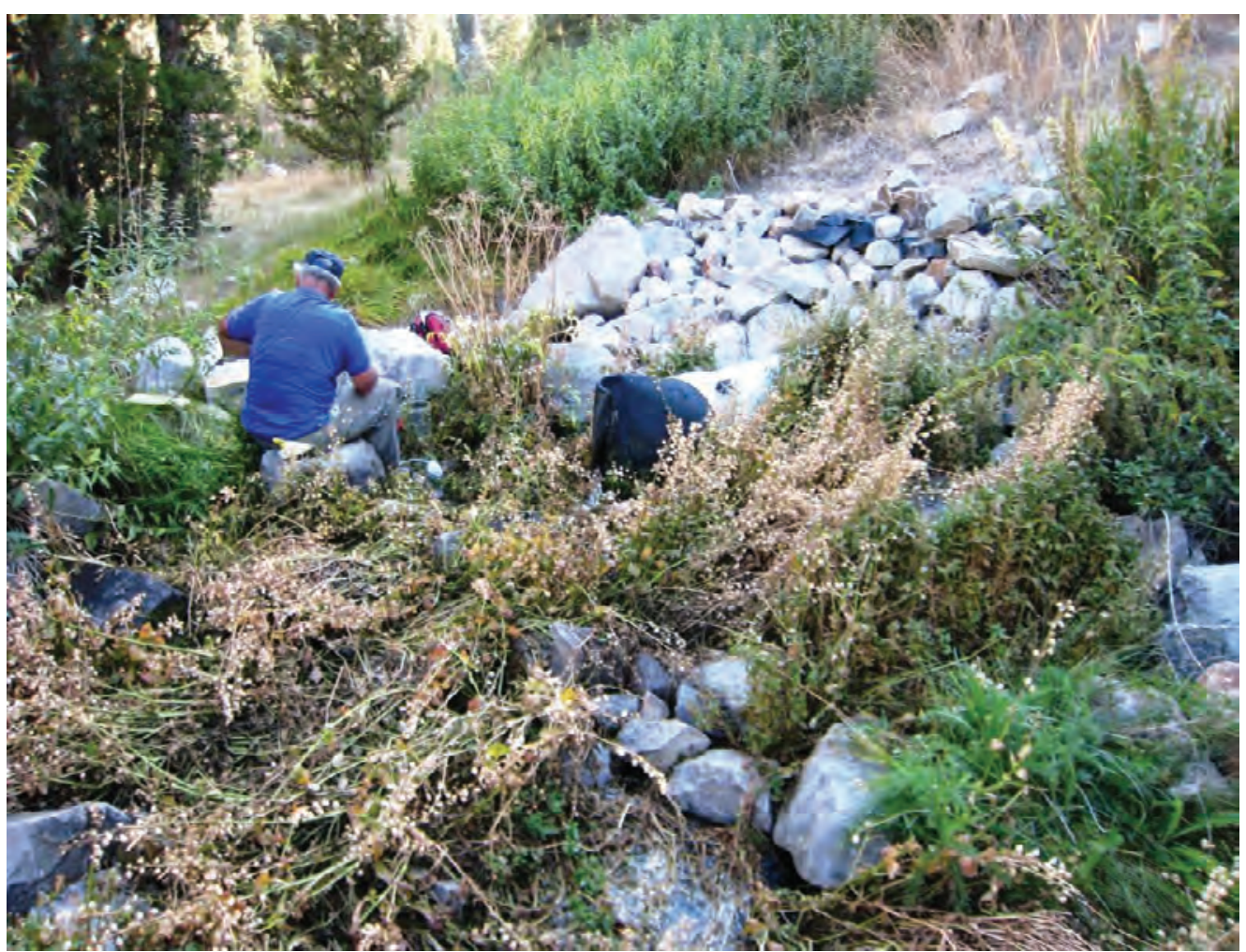

D. Site 4-Spring near upper Lehman Creek campground, view is to southwest.

\section{Figure 4.-Continued}

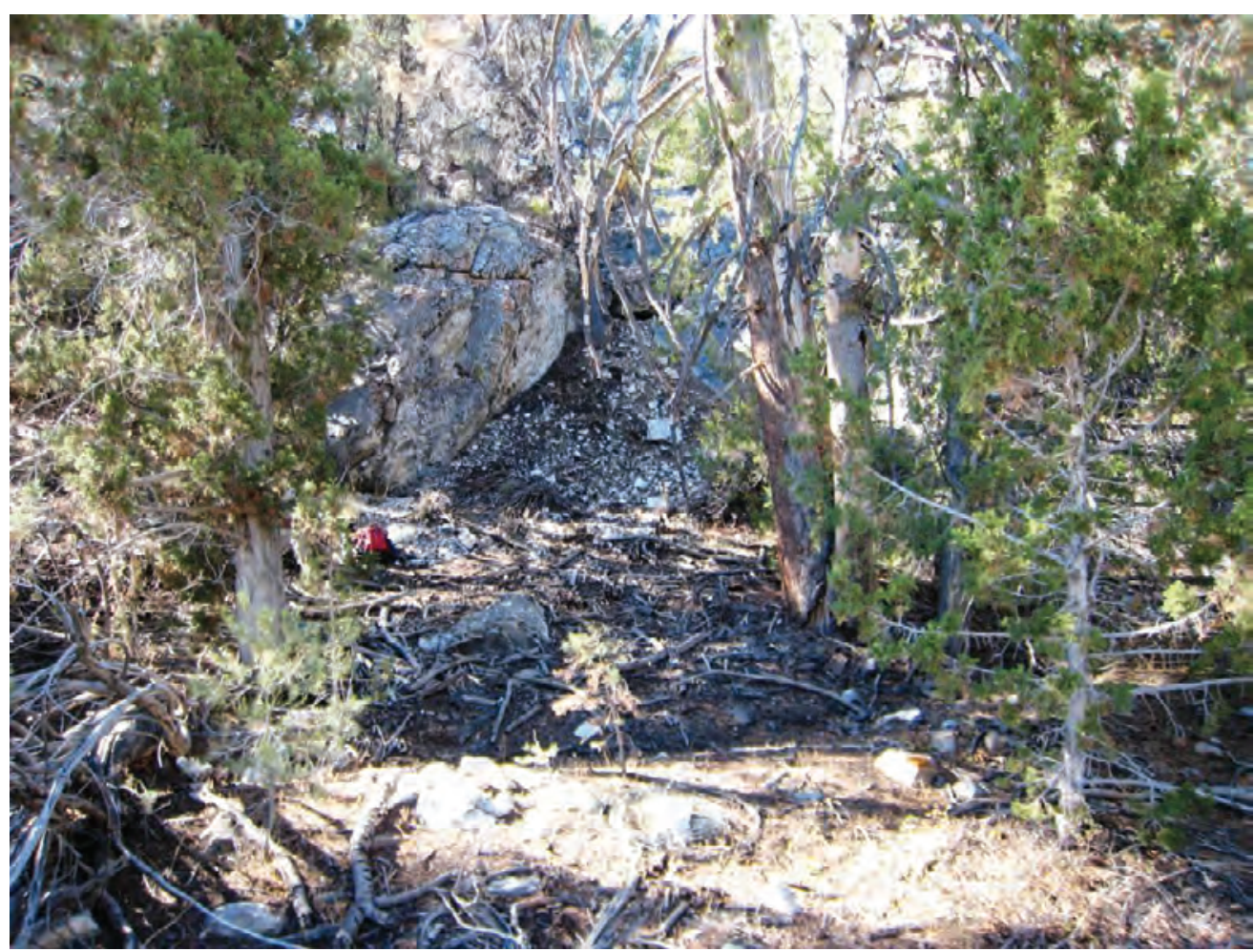

A. Site 5-Outcrop of Pole Canyon Limestone near Lehman Caves, view is to south.

Figure 5. Three rock sampling sites near Cave Springs, Great Basin National Park, Nevada, September 8, 2007. Site locations are shown in figure 2. 


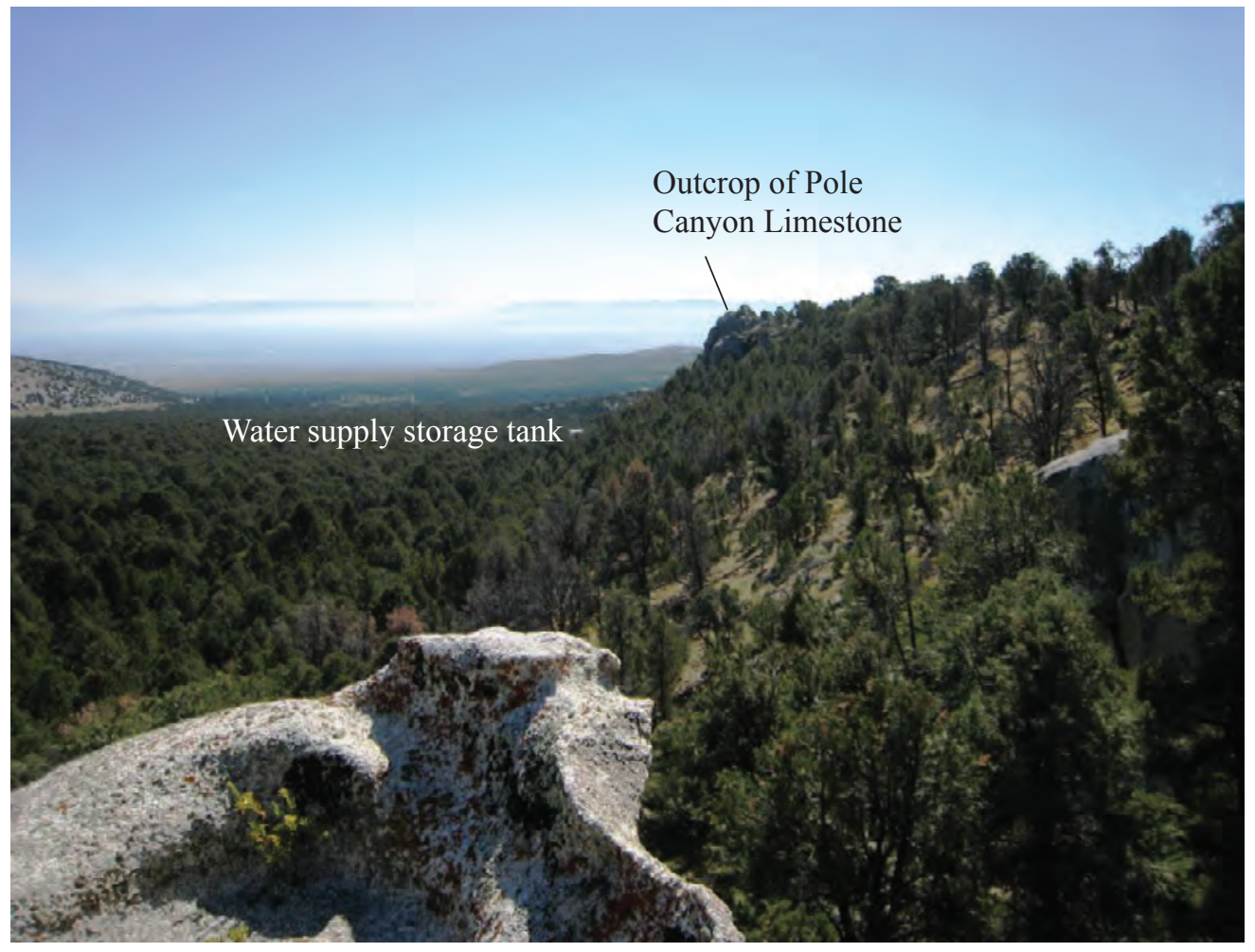

B. Site 6-Outcrop of Tertiary granite near Cave Springs, view is to east.

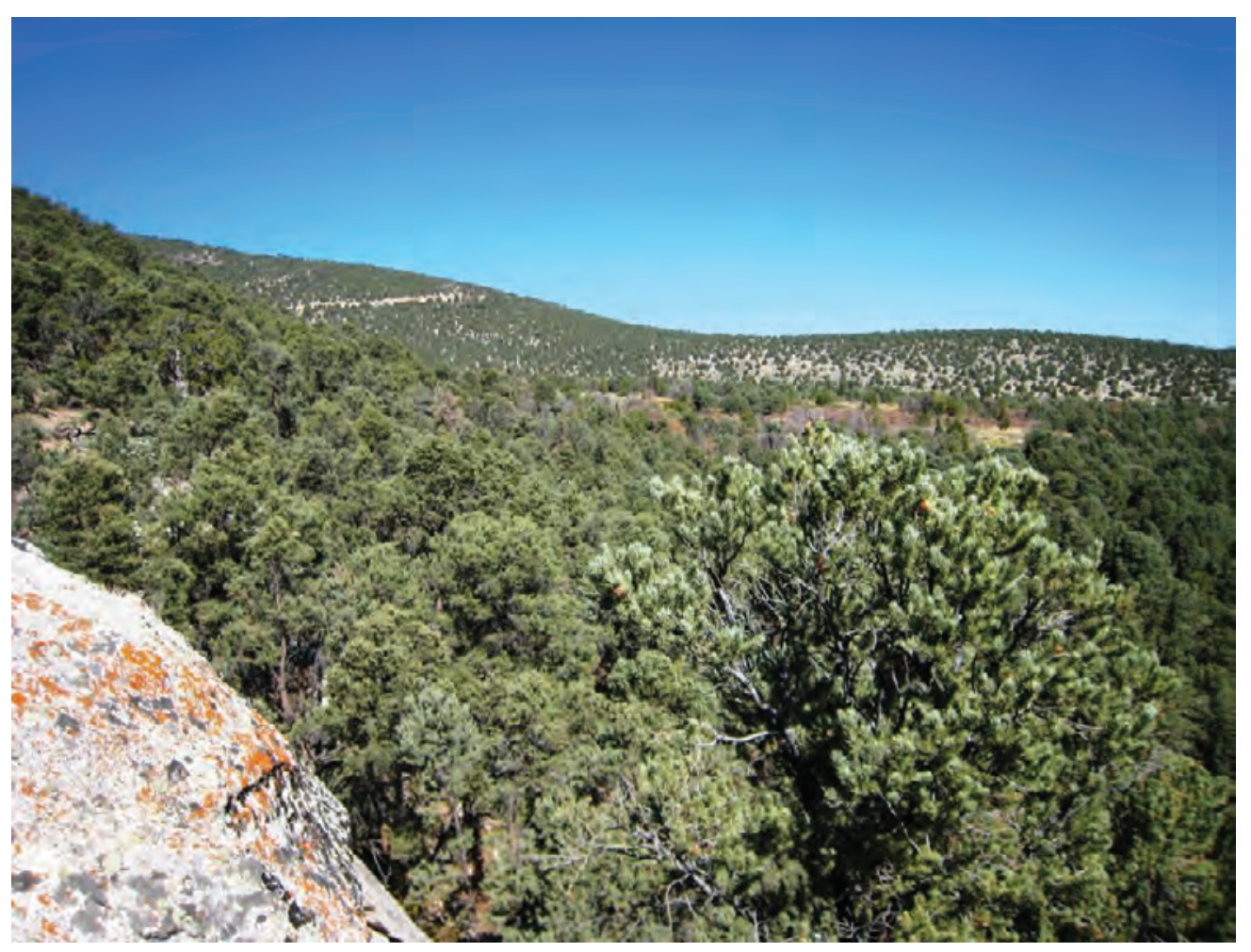

C. Site 6-Outcrop of Tertiary granite near Cave Springs, view is northwest toward Cave Springs.

Figure 5.-Continued 


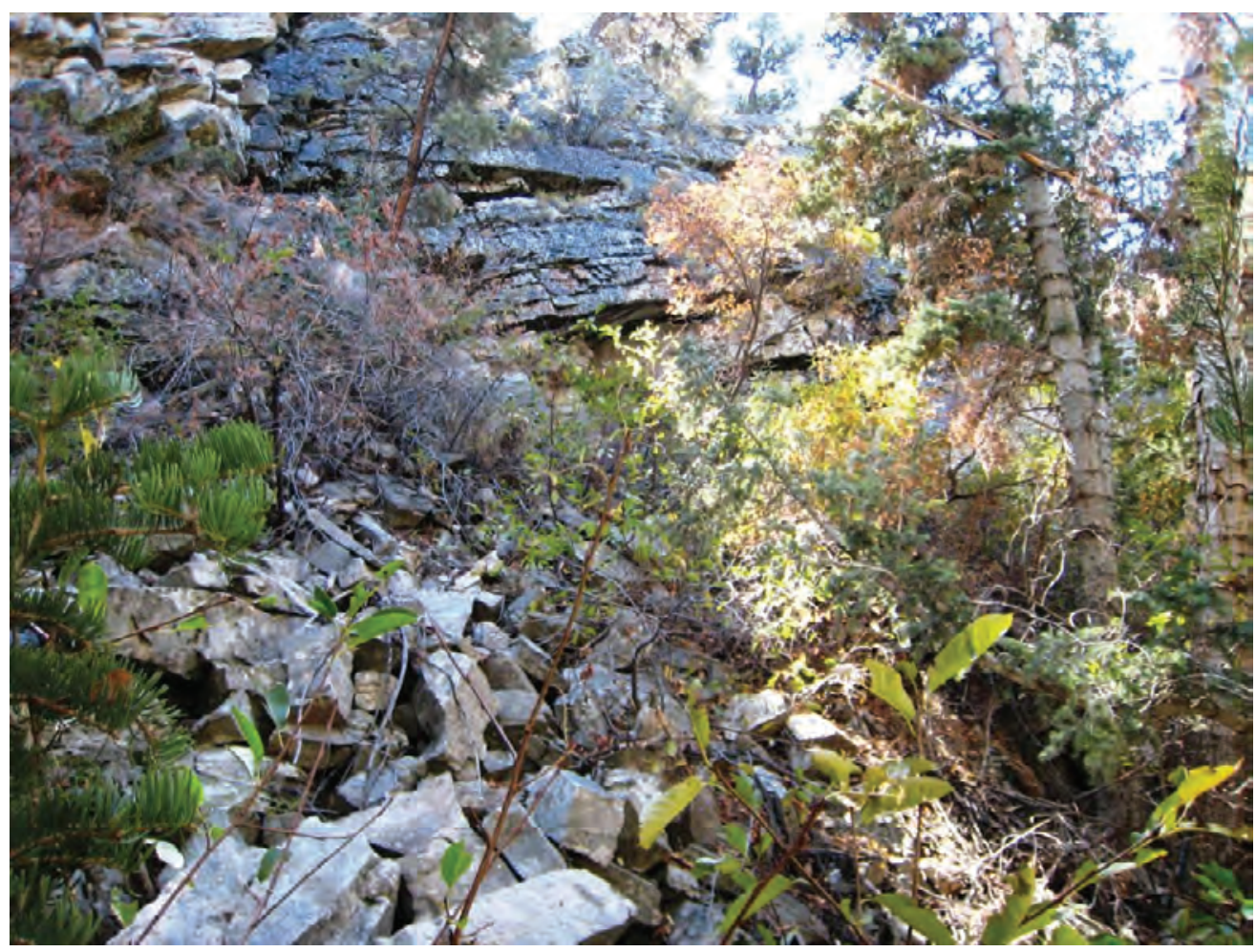

D. Site 7-Outcrop of Prospect Mountain Quartzite at upper Lehman Creek campground, view is to south.

\section{Figure 5.-Continued}

Table 1. Location and elevation of water and rock sampling sites at Great Basin National Park, Nevada.

[Site locations are shown in figure 2. Site identification No. was used to obtain data from National Water Information System (NWIS) database. Degrees, minutes, and seconds determined from Global Positioning System using horizontal coordinate information referenced to North American Datum of 1983 (NAD 83). Land surface altitude also determined from Global Positioning System using vertical coordinate information referenced to the North American Vertical Datum of 1929 (NAVD 29). The land surface altitude of Lehman Caves is near the entrance and is not that of the pool inside the cave. -, data not entered into NWIS database]

\begin{tabular}{|c|c|c|c|c|c|}
\hline \multirow{2}{*}{ Site No. } & \multirow{2}{*}{ Site name } & \multirow{2}{*}{$\begin{array}{c}\text { Site identification } \\
\text { No. }\end{array}$} & Latitude & Longitude & \multirow{2}{*}{$\begin{array}{c}\text { Land surface } \\
\text { altitude }\end{array}$} \\
\hline & & & \multicolumn{2}{|c|}{ (degrees minutes seconds) } & \\
\hline \multicolumn{6}{|c|}{ Water Samples } \\
\hline 2 & Pool in Lehman Caves & 390021114130801 & $39^{\circ} 00^{\prime} 21.1^{\prime \prime}$ & $114^{\circ} 13^{\prime} 11.7^{\prime \prime}$ & $6,830 \pm 20$ \\
\hline 3 & Spring near upper Lehman Creek campground & 390042114152601 & $39^{\circ} 00^{\prime} 42.2^{\prime \prime}$ & $114^{\circ} 15^{\prime} 29.9^{\prime \prime}$ & $7,920 \pm 30$ \\
\hline \multicolumn{6}{|c|}{ Rock Samples } \\
\hline 5 & Pole Canyon Limestone & - & $39^{\circ} 00^{\prime} 36.0^{\prime \prime}$ & $114^{\circ} 13^{\prime} 18.4^{\prime \prime}$ & $6,870 \pm 30$ \\
\hline 6 & Tertiary granite & - & $39^{\circ} 00^{\prime} 43.0^{\prime \prime}$ & $114^{\circ} 13^{\prime} 55.2^{\prime \prime}$ & $7,170 \pm 30$ \\
\hline 7 & Prospect Mountain Quartzite & - & $39^{\circ} 00^{\prime} 43.7^{\prime \prime}$ & $114^{\circ} 14^{\prime} 55.4^{\prime \prime}$ & $7,640 \pm 40$ \\
\hline
\end{tabular}




\section{Sampling Procedures}

Water for analysis of dissolved major ions plus aluminum, iron, bromide, and boron, and nutrients was collected by using a portable battery-operated peristaltic pump equipped with $\mathrm{C}$-flex tubing. The tubing was rinsed with deionized water prior to each sample collection. One end of the tubing was placed in the deepest part of a pool and water was pumped at a rate of about $1 \mathrm{~L} / \mathrm{min}$. A high volume Whatman capsule filter was attached to the other end after water had been pumped from the pool for at least 3 minutes.

All sample bottles were rinsed three times prior to collecting the sample by using either filtered or unfiltered water. Duplicate samples were collected at each site. Filtered water for dissolved cation and trace element analysis was collected in acid-rinsed 500-mL polyethylene bottles. These samples were preserved with $7.7 \mathrm{~N}$ Ultrex nitric acid to a $\mathrm{pH}$ of less than 2. Filtered water for dissolved-anion analysis was collected in $250-\mathrm{mL}$ polyethylene bottles. Additionally, unfiltered water was collected in $250-\mathrm{mL}$ polyethylene bottles. Water for low-level nutrient analysis was collected in $125-\mathrm{mL}$ polyethylene bottles. Filtered water was poured into amber bottles, whereas unfiltered water was poured into plain bottles. Water in the amber bottles was untreated, whereas water in the plain bottles was acidified to a $\mathrm{pH}$ less than $1 \mathrm{using} 1 \mathrm{~mL}$ of $4.5 \mathrm{~N}$ sulfuric acid. The low-level nutrient samples were kept at or below $4^{\circ} \mathrm{C}$ prior to analysis.

Unfiltered water for stable isotopes of hydrogen and oxygen was collected in 60-mL clear glass bottles. Filtered water for stable isotopes of carbon (carbon-13/carbon-12) was collected in 500-mL amber glass bottles and sealed with Teflon lined caps. Unfiltered water for strontium isotopes was collected in 500-mL polyethylene bottles.

Water for dissolved gas was collected in 150-mL clear glass serum bottles. The collection procedure was to place the serum bottle upside down at the bottom of the pool then slowly turn it towards the direction of flow. The bottle was filled and emptied three times prior to collecting a final sample. Once all air bubbles had been removed from the sample, a rubber stopper with needle placed to remove excess water was inserted into the open end of the bottle while the bottle was at the bottom of the pool. The needle was removed under water after the rubber stopper was in place.

Chlorofluorocarbon samples were collected in $125-\mathrm{mL}$ Boston round clear-glass bottles and sealed with white plastic caps with aluminum foil liner. The dip and fill method was used to collect samples at the bottom of each pool. Each bottle was filled and emptied three times prior to collecting a sample. The foil-lined cap was placed and tightened while the bottle was at the bottom of the pool with the bottle completely filled with water. A total of five chlorofluorocarbon samples were collected at each site.
Measurements of temperature, specific conductance, $\mathrm{pH}$, and dissolved oxygen were made by placing the probe for each measurement into the pool. Specific conductance and $\mathrm{pH}$ were calibrated to standards at the time of sampling. Dissolved oxygen was calibrated once at the beginning of sampling. Alkalinity also was determined at the time of sampling. A 50-mL sample of filtered water was titrated by using an inflection-point method with $0.16 \mathrm{~N}$ sulfuric acid. Bicarbonate concentrations were calculated from alkalinity.

Fresh rock samples were collected at the three sampling sites by removing weathered surfaces with a standard rock hammer. About $2 \mathrm{~kg}$ of rock samples were placed in yellow plastic sample bags.

\section{Analyses of Water and Rock Samples}

The water samples were shipped to four U.S. Geological Survey (USGS) laboratories depending on the type of analysis required. The types of analyses and the laboratories used are summarized in table 2. Water samples collected for major dissolved ions, aluminum, boron, and low-level nutrients were sent the USGS National Water Quality Laboratory (NWQL) in Lakewood, Colorado. Water samples collected for stable isotopes of hydrogen and oxygen were sent to the USGS Reston Stable Isotope Laboratory (RSIL) in Reston, Virginia. Water samples collected for dissolved gases and chlorofluorocarbons were sent to the USGS Chlorofluorocarbon (CFC) Laboratory in Reston, Virginia. Water and rock samples for strontium, strontium isotope ratio $\left({ }^{87} \mathrm{Sr} /{ }^{86} \mathrm{Sr}\right)$, dissolved inorganic carbon, and stable carbon isotopes $\left({ }^{13} \mathrm{C}\right.$ and $\left.{ }^{12} \mathrm{C}\right)$ were sent to the Yucca Mountain Project Environmental Laboratory in Lakewood, Colorado.

Results of all analyses done by the different laboratories are stored in the USGS National Water Information System (NWIS) database (http://waterdata.usgs.gov/nv/nwis/nwis). The analytical procedures used by the NWQL are available at http://nwql.cr.usgs.gov/usgs/catalog/index.cfm. Analytical procedures used by the RSIL are available at http://isotopes. usgs.gov/Methods.htm and analytical procedures used by the CFC Laboratory are available at http://water.usgs.gov/ $\underline{\text { lab. }}$. Sampling and analytical procedures used by the Yucca Mountain Project Environmental laboratory for analyzing strontium concentrations and strontium ratios in water and rock are described in Paces and others (2007). Procedures for analyzing total dissolved inorganic carbon and stable carbon isotopes in water are listed in two technical procedures of the Yucca Mountain Project as part of the U.S. Department of Energy's requirements for quality assurance and quality control (R.L. Moscati, U.S. Geological Survey, Lakewood, Colorado, written commun., 2007). Procedures for analyzing 
Table 2. Selected constituents analyzed in water and rock samples collected near Cave Springs at Great Basin National Park, Nevada, and U.S. Geological Survey laboratories used for analysis.

[All analyses completed at U.S. Geological Survey laboratories]

\begin{tabular}{lccl}
\hline \multicolumn{1}{c}{ Constituent } & Water samples & Rock samples & \\
\hline Chlorofluorocarbons & Yes & No & Chlorofluorocarbon Laboratory \\
Dissolved gases & Yes & No & Chlorofluorocarbon Laboratory \\
Dissolved inorganic carbon & Yes & No & Yucca Mountain Project Environmental Laboratory \\
Low-level nutrients & Yes & No & National Water Quality Laboratory \\
Major and trace elements & Yes & No & National Water Quality Laboratory \\
Stable isotopes carbon & Yes & Yes $^{1}$ & Yucca Mountain Project Environmental Laboratory \\
Oxygen & No & Yes $^{1}$ & Yucca Mountain Project Environmental Laboratory \\
Hydrogen and oxygen & Yes & No & Reston Stable Isotope Laboratory \\
Strontium & Yes & Yes & Yucca Mountain Project Environmental Laboratory \\
\hline
\end{tabular}

${ }^{1}$ One rock sample of Pole Canyon Limestone.

${ }^{2}$ Includes dissolved-strontium concentration in water.

stable carbon and oxygen isotopes in rock are listed in a third technical procedures manual (R.L. Moscati, U.S. Geological Survey, Lakewood, Colorado, written commun., 2007).

Because of the limited number of samples collected, no field blanks were analyzed. However, all laboratories used to analyze the water samples have been quality assured. Standard laboratory procedures for quality assurance at the NQWL are documented by Pirkey and Glodt (1998) and Maloney (2005). Standard procedures for quality assurance at the RSIL are documented at http://isotopes.usgs.gov/Quality.htm. Duplicate samples (two each for dissolved gases and five each for chlorofluorocarbon analyses) were sent to the CFC laboratory as part of their quality-assurance procedure. Multiple tests of the samples were done on the samples sent to the laboratory. Only one sample from the permanent pool in Lehman Caves differed greatly from two other duplicate samples for analysis of CFC-11, but CFC-11 concentrations were greater than the current concentration in the atmosphere in all three samples collected at this location.

\section{Water Chemistry}

Major- and trace-element concentrations in water collected from the four sites are listed in table 3 . The most dilute water was from the spring that discharges from glacial deposits near upper Lehman Creek campground; whereas, water from the permanent pool in Lehman Caves had the highest concentration of dissolved minerals.

Low-level nutrient concentrations are listed in table 4. Ammonia concentrations were below detection in all four samples and the maximum concentration of total nutrient nitrogen (ammonia, nitrate, nitrite, and organic nitrogen) was from the water sample collected from the permanent pool in Lehman Caves $(0.94 \mathrm{mg} / \mathrm{L}$ as N). Dissolved phosphorus and orthophosphate were uniformly low and ranged from only $0.02 \mathrm{mg} / \mathrm{L}$ as $P$ in water from the spring near upper Lehman Creek campground and Marmot Spring (sites 3 and 4, respectively) to about $0.05 \mathrm{mg} / \mathrm{L}$ as $P$ in water collected from the permanent pool in Lehman Caves (site 2).

Specific conductance is a simple measurement typically used to ascertain the relative ionic concentration of water. However, because natural waters contain a variety of ionic and undissociated species of widely varying concentrations, the determination may not be related simply to individual or dissolved-solids concentrations (Hem, 1985, p. 67). With this precautionary note, the relation between specific conductance and dissolved solids among the four samples is exceptional (fig. 6). Specific conductance in water samples ranged from only $36 \mu \mathrm{S} / \mathrm{cm}$ at $25^{\circ} \mathrm{C}$ from the spring near upper Lehman Creek campground (site 3) to $440 \mu \mathrm{S} / \mathrm{cm}$ at $25^{\circ} \mathrm{C}$ from the permanent pool in Lehman Caves. Cave Springs has higher specific conductance and dissolved solids than that of the spring near upper Lehman Creek campground and Marmot Spring but less than that from the pool in Lehman Caves.

The low specific conductance and dissolved solids of the spring near upper Lehman Creek campground and water in Lehman Creek $\left(30-40 \mu \mathrm{S} / \mathrm{cm}\right.$ at $25^{\circ} \mathrm{C}$ as reported by Elliott and others, 2006, p. 32) is within the range of snowmelt in the Sierra Nevada (Feth and others, 1964). Although the specific conductance of snowmelt at Great Basin National Park was not measured, the low specific conductance and dissolved solids of the spring and Lehman Creek indicates rapid flow through the glacial deposits and little dissolution of Prospect Mountain Quartzite. 
Table 3. Concentrations of selected dissolved constituents in water collected from Cave Springs, a permanent pool in Lehman Caves, and two nearby springs at Great Basin National Park, Nevada.

[Site locations are shown in figure 2. Analyses were done by laboratories listed in table 2. Cave Springs prior to reconstruction of water-collection system: Analyses of Cave Springs water prior to reconstruction of water-collection system in 1996 (Gretchen Baker, National Park Service, Great Basin National Park, written commun., 2008). Nevada State Health Laboratory collected and analyzed sample. All values are in milligrams per liter except for specific conductance, $\mathrm{pH}$, and temperature. Temperature is rounded to nearest 0.1 degree Celsius $\left({ }^{\circ} \mathrm{C}\right) ; \mathrm{pH}$ is rounded to nearest 0.01 unit. Symbols: - , not determined; $<$, less than; E, estimated]

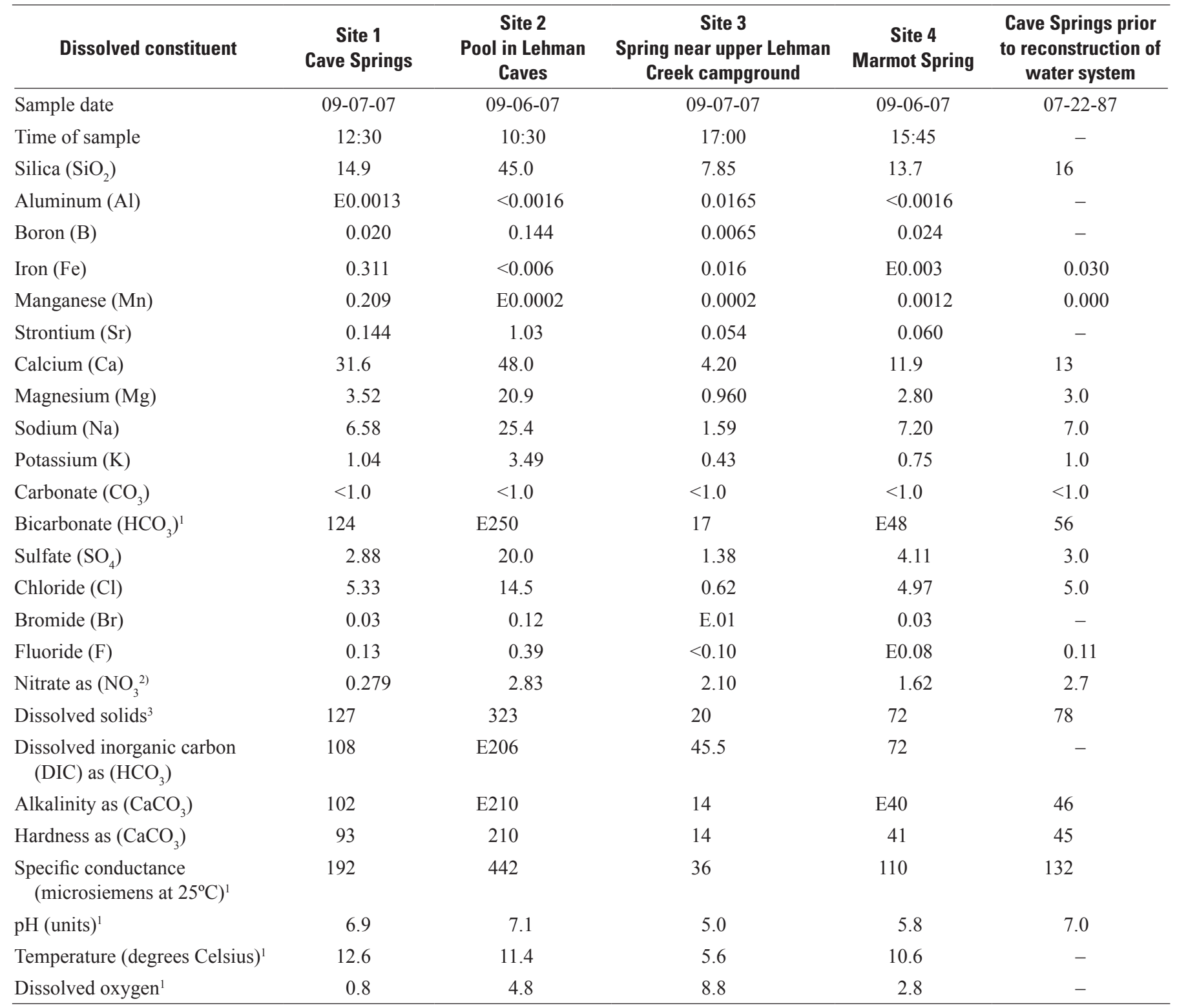

\footnotetext{
${ }^{1}$ Field measurement.

${ }^{2}$ Nitrate concentrations reported as nitrate $\left(\mathrm{NO}_{3}\right)$ and were calculated for the four samples collected in September 2007 as the difference in nitrate-plus-nitrite and nitrite concentrations listed in table 4.

${ }^{3}$ Residue upon evaporation at $180^{\circ} \mathrm{C}$.
} 
Table 4. Concentrations of nutrients in water collected from Cave Springs, a permanent pool in Lehman Caves, and two nearby springs at Great Basin National Park, Nevada.

[Site locations are shown in figure 2. Nutrient analyses were done by U.S. Geological Survey National Water Quality Laboratory. All values are in milligrams per liter as reported by the laboratory. Symbols: <, less than; E, estimated]

\begin{tabular}{|c|c|c|c|c|}
\hline Nutrient & $\begin{array}{c}\text { Site } 1 \\
\text { Cave Springs }\end{array}$ & $\begin{array}{c}\text { Site } 2 \\
\text { Pool in Lehman } \\
\text { Caves }\end{array}$ & $\begin{array}{c}\text { Site } 3 \\
\text { Spring near upper } \\
\text { Lehman Creek } \\
\text { campground }\end{array}$ & $\begin{array}{c}\text { Site } 4 \\
\text { Marmot Spring }\end{array}$ \\
\hline Sample date & 09-07-07 & 09-06-07 & 09-07-07 & 09-06-07 \\
\hline Time of sample & $12: 30$ & $10: 30$ & $17: 00$ & $15: 45$ \\
\hline Ammonia $\left(\mathrm{NH}_{3}\right)$ as nitrogen $(\mathrm{N})$ (filtered) & $<0.02$ & $<0.02$ & $<0.02$ & $<0.02$ \\
\hline Nitrate $\left(\mathrm{NO}_{3}\right)+$ nitrite $\left(\mathrm{NO}_{2}\right)$ as $\mathrm{N}$ (filtered) & 0.065 & 0.640 & 0.476 & 0.367 \\
\hline Nitrite $\left(\mathrm{NO}_{2}\right)$ as $\mathrm{N}$ (filtered) & E0.002 & E0.001 & E0.001 & E0.001 \\
\hline Total nutrient nitrogen as $\mathrm{N}$ (filtered) ${ }^{1}$ & 0.12 & 0.94 & 0.50 & 0.40 \\
\hline Total nutrient nitrogen as $\mathrm{N}$ (unfiltered) ${ }^{1}$ & 0.45 & 0.94 & 0.51 & 0.64 \\
\hline Phosphorus (P) (filtered) & 0.035 & 0.048 & 0.017 & 0.022 \\
\hline Orthophosphate $\left(\mathrm{PO}_{4}\right)$ as $\mathrm{P}$ (filtered) & 0.032 & 0.052 & 0.017 & 0.022 \\
\hline Total phosphorus as $\mathrm{P}$ (unfiltered) & 0.115 & 0.051 & 0.020 & 0.061 \\
\hline
\end{tabular}

${ }^{1}$ Total nutrient nitrogen includes ammonia, nitrate, nitrite, and organic nitrogen in sample.

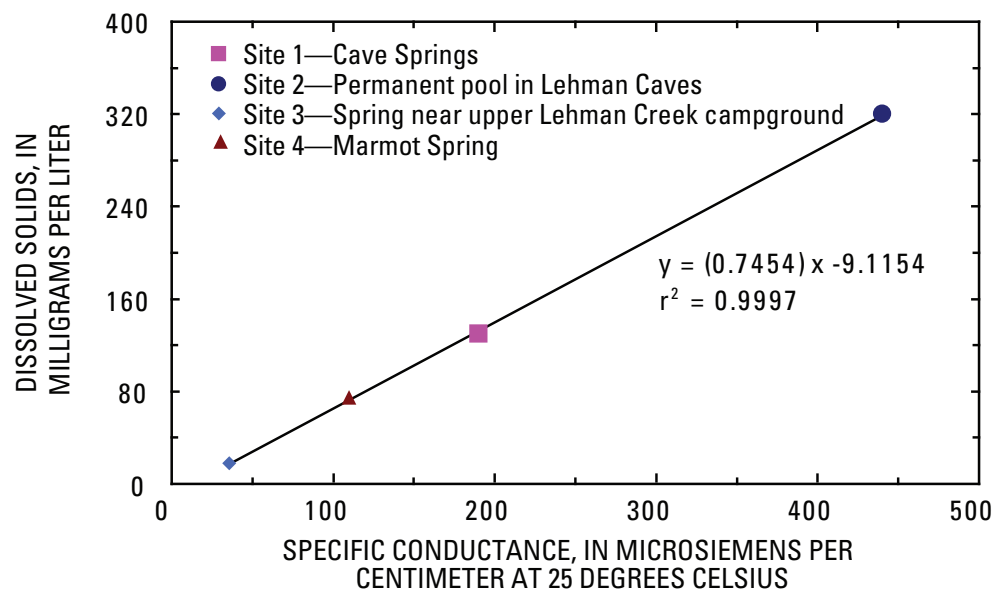

Figure 6. Relation between specific conductance and dissolved solids in water sampled from Cave Springs, a permanent pool in Lehman Caves, and two nearby springs, Great Basin National Park, Nevada, September 2007. Site locations are shown in figure 2. 
The reason for the good correlation between specific conductance and dissolved solids is that the dominant dissolved ions in all four samples are calcium, magnesium, and bicarbonate (fig. 7) and the concentrations of dissolved ionic species increases (1) with increased residence times (Marmot Spring) and (2) contact with the Pole Canyon Limestone (Lehman Caves). Although the water in the permanent pool in Lehman Caves has dissolved solids 16 times more than that from the spring near upper Lehman
Creek campground, the overall proportions of the dissolved species are nearly the same. The only marked difference is that the ratio of magnesium to calcium is 0.45 at Lehman Caves, which is nearly twice the ratio of the spring near upper Lehman Creek campground. The increase in magnesium relative to calcium in the pool at Lehman Caves compared to the other samples is caused by the chemical precipitation of calcium carbonate that forms the many types of speleothems in the caves.

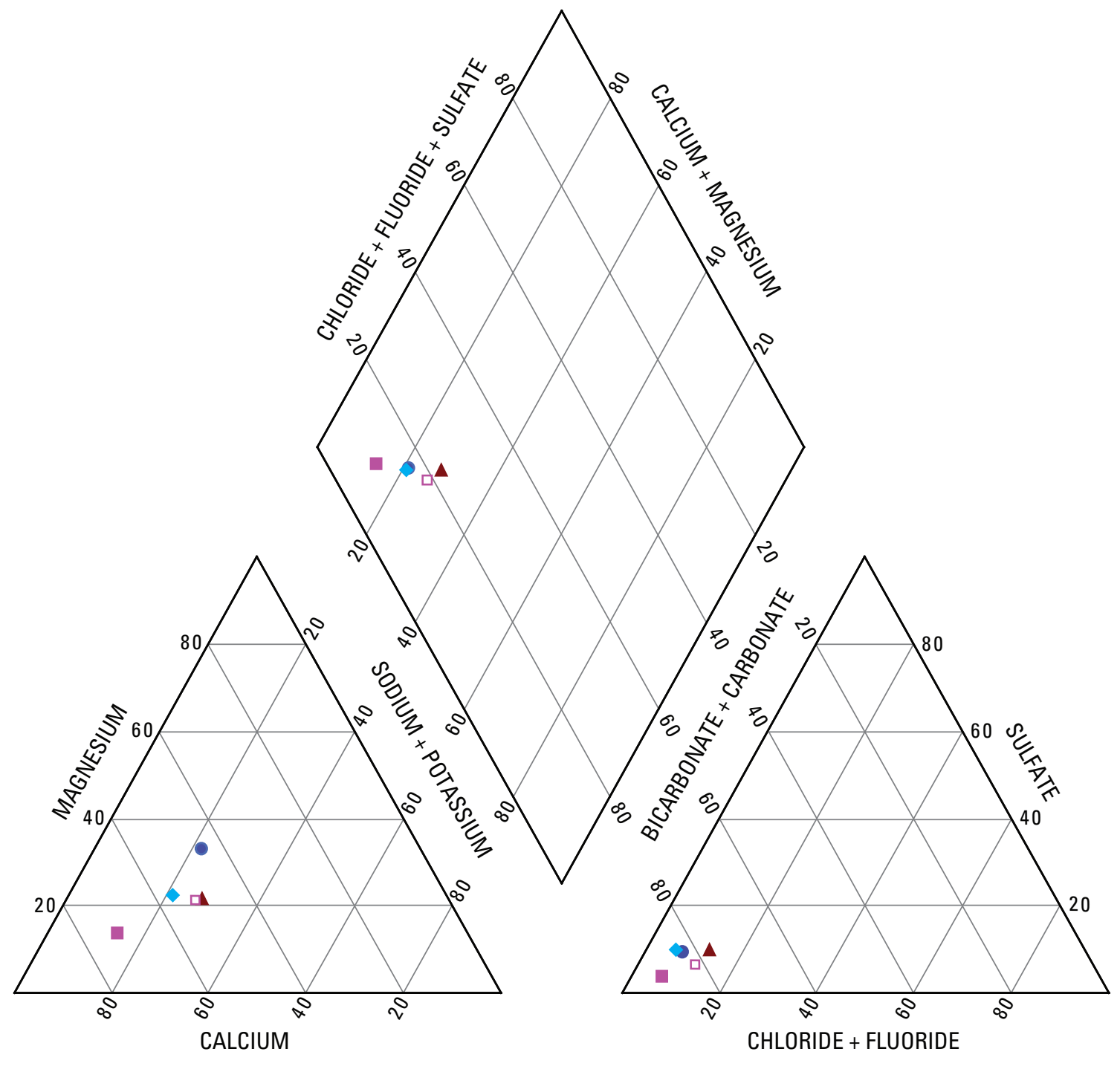

EXPLANATION

- Site 1-Cave Springs

- Site 2-Permanent pool in Lehman Caves

- Site 3-Spring near upper Lehman Creek campground

- Site 4-Marmot Spring

$\square$ Cave Springs prior to reconstruction of water-collection system

Figure 7. Distribution of water chemistry from samples collected from Cave Springs, a permanent pool in Lehman Caves, and two nearby springs, Great Basin National Park, Nevada, September 2007. Site locations are shown in figure 2. 
Water from Marmot Spring had proportionately more chloride and fluoride than either the spring near upper Lehman Creek campground or the pool in Lehman Caves, whereas Cave Springs had proportionately more calcium and bicarbonate and less magnesium and sulfate. An increase in calcium and bicarbonate at Cave Springs can be explained by dissolution of limestone without much magnesium. A decrease in sulfate is explained by the reduction of sulfate to hydrogen sulfide (dissolved oxygen is less than $1 \mathrm{mg} / \mathrm{L}$ ). A faint but distinct hydrogen-sulfide smell was present during sampling. The chemical composition of Cave Springs in July 1987, 9 years prior to the reconstruction of the water supply at the springs, was nearly the same as Marmot Spring. The difference in chemistry before and after the reconstruction indicates that the reconstruction somehow altered the chemical composition of water discharging from Cave Springs.

\section{Source of Water to Cave Springs}

\section{Stable Isotopes}

Stable isotope values in water from the four water samples are listed in table 5. Values of stable isotopes of ${ }^{2} \mathrm{H}$ (deuterium or D), ${ }^{18} \mathrm{O}$, and ${ }^{13} \mathrm{C}$ are reported in delta $(\delta)$ notation, whereas the ratio of strontium $\left({ }^{87} \mathrm{Sr}\right.$ to $\left.{ }^{86} \mathrm{Sr}\right)$ is expressed simply as a ratio. The delta notation is used to distinguish variations in the concentration of the stable isotopes among samples and is determined as the difference between the isotopic ratio in a sample and the ratio in a reference standard divided by the ratio in the reference standard (Clark and Fritz, 1997, p. 6). The values are expressed as parts per thousand or permil difference from the reference standard. The reference standard for determining $\delta \mathrm{D}$ and $\delta^{18} \mathrm{O}$ in water is the Vienna Standard Mean Ocean Water (VSMOW). The reference standard for oxygen and carbon in carbonate minerals is the internal calcite structure from a fossil Belemnitella Americana from the Cretaceous Pee Dee Formation of South Carolina (PDB; Craig, 1957; Clark and Fritz, 1997, p. 9). A negative value of $\delta \mathrm{D}, \delta^{18} \mathrm{O}$, and $\delta^{3} \mathrm{C}$ represents water with less $\mathrm{D},{ }^{18} \mathrm{O}$, and ${ }^{13} \mathrm{C}$ relative to ${ }^{1} \mathrm{H},{ }^{16} \mathrm{O}$, and ${ }^{12} \mathrm{C}$, respectively, than the reference standard.

The global meteoric waterline (Craig, 1961) shows the general relation between $\delta \mathrm{D}$ and $\delta^{18} \mathrm{O}$ in precipitation whereby isotopically lighter values (more negative) are associated with cold regions and winter precipitation and isotopically heavier values (less negative) are associated with warm regions and summer precipitation (fig. 8). A local meteoric waterline was estimated for Great Basin National Park from the isotopic composition of summer and winter precipitation reported by Friedman and others (2002). Composite samples of precipitation were collected at three specially designed gages near Great Basin National Park between April 1991 and June 1997 (Friedman and others, 2002, p. ACL 15-5).

Table 5. Stable isotopes of hydrogen, oxygen, carbon, and strontium in water collected from Cave Springs, a permanent pool in Lehman Caves, and two nearby springs at Great Basin National Park, Nevada.

[Site locations are shown in figure 2. Analyses were done by laboratories listed in table 2. Sample dates and times for sites 1-4 are listed in tables 3 and $\underline{4}$. Cave Springs prior to reconstruction of water-collection system: Analyses of Cave Springs water prior to reconstruction of water-collection system in 1996 are from Acheampong (1992). Average of 15 analyses from samples collected between August 15, 1990, and September 15, 1991. Environmental Isotope Laboratory of the Water Resources Center at the Desert Research Institute in Las Vegas, Nevada, did the analysis. Symbol: -, not determined]

\begin{tabular}{|c|c|c|c|c|c|}
\hline Stable isotope & $\begin{array}{c}\text { Site } 1 \\
\text { Cave Springs }\end{array}$ & $\begin{array}{c}\text { Site } 2 \\
\text { Pool in Lehman } \\
\text { Caves }\end{array}$ & $\begin{array}{c}\text { Site } 3 \\
\text { Spring near upper } \\
\text { Lehman Creek } \\
\text { campground }\end{array}$ & $\begin{array}{c}\text { Site } 4 \\
\text { Marmot Spring }\end{array}$ & $\begin{array}{l}\text { Cave Springs prior } \\
\text { to reconstruction of } \\
\text { water system }\end{array}$ \\
\hline $\begin{array}{l}\text { Oxygen-18/oxygen-16 }\left({ }^{18} \mathrm{O} /{ }^{16} \mathrm{O}\right) \text { as } \delta^{18} \mathrm{O} \\
\text { in permil }{ }^{1}\end{array}$ & -15.5 & -12.2 & -14.7 & -15.4 & -15.7 \\
\hline Strontium-87/strontium- $86\left({ }^{87} \mathrm{Sr} /{ }^{86} \mathrm{Sr}\right)^{3}$ & 0.71713 & 0.71121 & 0.71813 & 0.71271 & - \\
\hline
\end{tabular}

${ }^{1}$ Ratios reported in delta $(\delta)$ notation as parts per thousand (permil). Delta is the relative difference between the ratios of hydrogen-2 or deuterium to hydrogen-1 $\left({ }^{2} \mathrm{H} /{ }^{1} \mathrm{H}\right)$ or oxygen-18 to oxygen-16 $\left({ }^{18} \mathrm{O} /{ }^{16} \mathrm{O}\right)$ in water samples to the respective ratios in Vienna Standard Mean Ocean Water (VSMOW; Giofiantini, 1978). A negative value represents water with less ${ }^{2} \mathrm{H}$ relative to ${ }^{1} \mathrm{H}$ or ${ }^{18} \mathrm{O}$ relative to ${ }^{16} \mathrm{O}$ than VSMOW. Standard error at 95 -percent confidence level is 2 permil for $\delta \mathrm{D}$ and 0.2 permil for $\delta^{18} \mathrm{O}$.

${ }^{2}$ Ratios reported in delta $(\delta)$ notation as parts per thousand (permil). Delta is the relative difference between the ratios of carbon-13 to carbon-12 $\left({ }^{13} \mathrm{C} /{ }^{12} \mathrm{C}\right)$ in water samples to that in a sample of belemnite from the Pee Dee Formation of South Carolina (PDB; Craig, 1957). A negative value represents a sample with less ${ }^{13} \mathrm{C}$ relative to ${ }^{12} \mathrm{C}$ than in the standard sample of PDB. Standard error at 95 -percent confidence level is 0.5 permil.

${ }^{3}$ Ratios are based on repetitive analyses on the seawater standard, EN-1. The error on the ratio of strontium- 87 to strontium- $86\left({ }^{87} \mathrm{Sr} /{ }^{86} \mathrm{Sr}\right)$ is \pm 0.00005 at the 95-percent confidence level. 


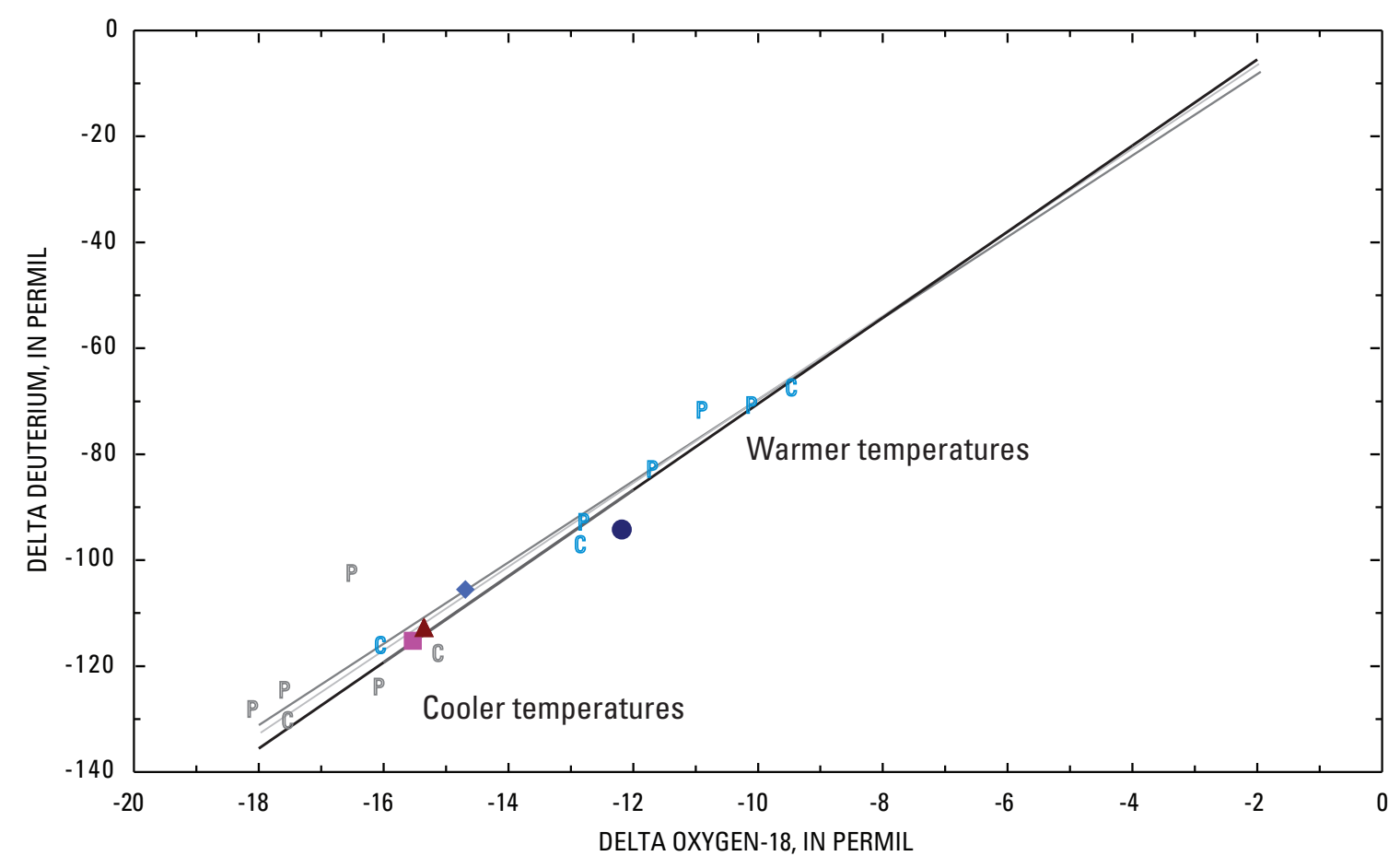

EXPLANATION

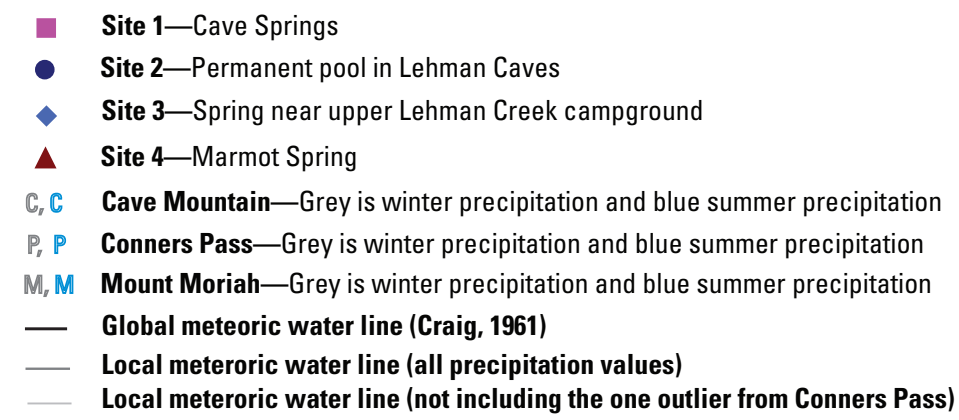

Figure 8. Deuterium and oxygen-18 in water samples collected September 2007 from Cave Springs, a permanent pool in Lehman Caves, and two nearby springs, Great Basin National Park, Nevada, in relation to precipitation collected from Cave Mountain, Connors Pass, and Mount Moriah in neighboring mountain ranges between April 1991 and June 1997. Delta deuterium and oxygen-18 values from precipitation are from Friedman and others (2002). Locations of precipitation sites are shown in figure 1 and water sampling sites are shown in figure 2.

The composite samples for summer precipitation typically spanned May through October and the composite samples for winter precipitation typically spanned November through April. Locations of the three precipitation gages are shown in figure 1 and were designated as Cave Mountain (elevation of $10,650 \mathrm{ft}$ above mean sea level), Connors Pass (elevation of $8,275 \mathrm{ft}$ above mean sea level), and Mount Moriah (elevation of 9,375 ft above mean sea level) by Friedman and others (2002, p. ACL 15-4). Although $\delta$ D was determined routinely for precipitation during summer and winter, $\delta^{18} \mathrm{O}$ was not always analyzed; therefore, the number of precipitation samples used to determine the local meteoric waterline in figure 8 is less than the total number of samples. The local meteoric waterline determined from regression of the data from the three precipitation gages is close to the global meteoric waterline and when the one outlier from Connors Pass is excluded from the regression, the local meteoric waterline is nearly the same as the global meteoric waterline. 
Cave Springs, Marmot Spring, and the spring near upper Lehman Creek campground fall on the global and local meteoric waterlines. This indicates that water discharging from the three springs has not been altered greatly by evaporation or by chemical reactions with calcite in the rocks. The $\delta \mathrm{D}$ and $\mathrm{d}^{18} \mathrm{O}$ of Cave Springs and Marmot Spring are isotopically the lightest (most negative values) of the four samples. The values at these two springs essentially are the same (95-percent confidence level) and indicate the source of water to these springs primarily is winter snowmelt.

Water from the spring near upper Lehman Creek campground is slightly heavier and colder (tables 3 and $\underline{2}$, respectively) relative to Cave Springs or Marmot Spring. The slightly heavier $\delta \mathrm{D}$ at the spring near upper Lehman Creek campground is within the range of $\delta \mathrm{D}$ in Lehman Creek collected at an altitude of 9,600 ft upstream from the spring in August 1990 and September 1990 (Acheampסong, 1992, location LC2, p. 96). The $\delta$ D of Lehman Creek at sampling site LC2 (see fig. 2 for location) ranged from -101 in September 1990 to -114 in January 1991. The stable isotope composition of Lehman Creek was interpreted to be a combination of winter and summer precipitation as well as evaporated lake water from three shallow lakes in the headwater area (Acheampong, 1992, p. 58).
The isotopically heavier $\delta \mathrm{D}$ and $\delta^{18} \mathrm{O}$ values in water from the permanent pool in Lehman Caves indicates that water in the caves was derived from local precipitation that has a greater fraction of summer precipitation than the samples from the three springs. Lehman Caves lies above the water table and water in the pools is from infiltration of precipitation through the soil and limestone above the caves. The water in the permanent pool does not fall on either the global or local meteoric waterline indicating it is slightly heavier in ${ }^{18} \mathrm{O}$ relative to deuterium compared with precipitation. The enrichment indicates that water in the cave has undergone some evaporation.

The $\delta^{13} \mathrm{C}$ in water from the spring near upper Lehman Creek campground had a value of -16 permil PDB. This spring had the least dissolved inorganic carbon of the four sites sampled (fig. 9), which is expected because little carbonate is in the quartzite rocks (Lee and Van Loenen, 1971, p. 8) and because of minimal soil development in the glaciated drainage upstream of the spring. The $\delta^{13} \mathrm{C}$ in water from Cave Springs is heavier and dissolved inorganic carbon is more relative to water from Marmot Spring and the spring near the upper Lehman Creek campground but less than water from the pool in Lehman Caves. The high values of $\delta^{13} \mathrm{C}$ and dissolved

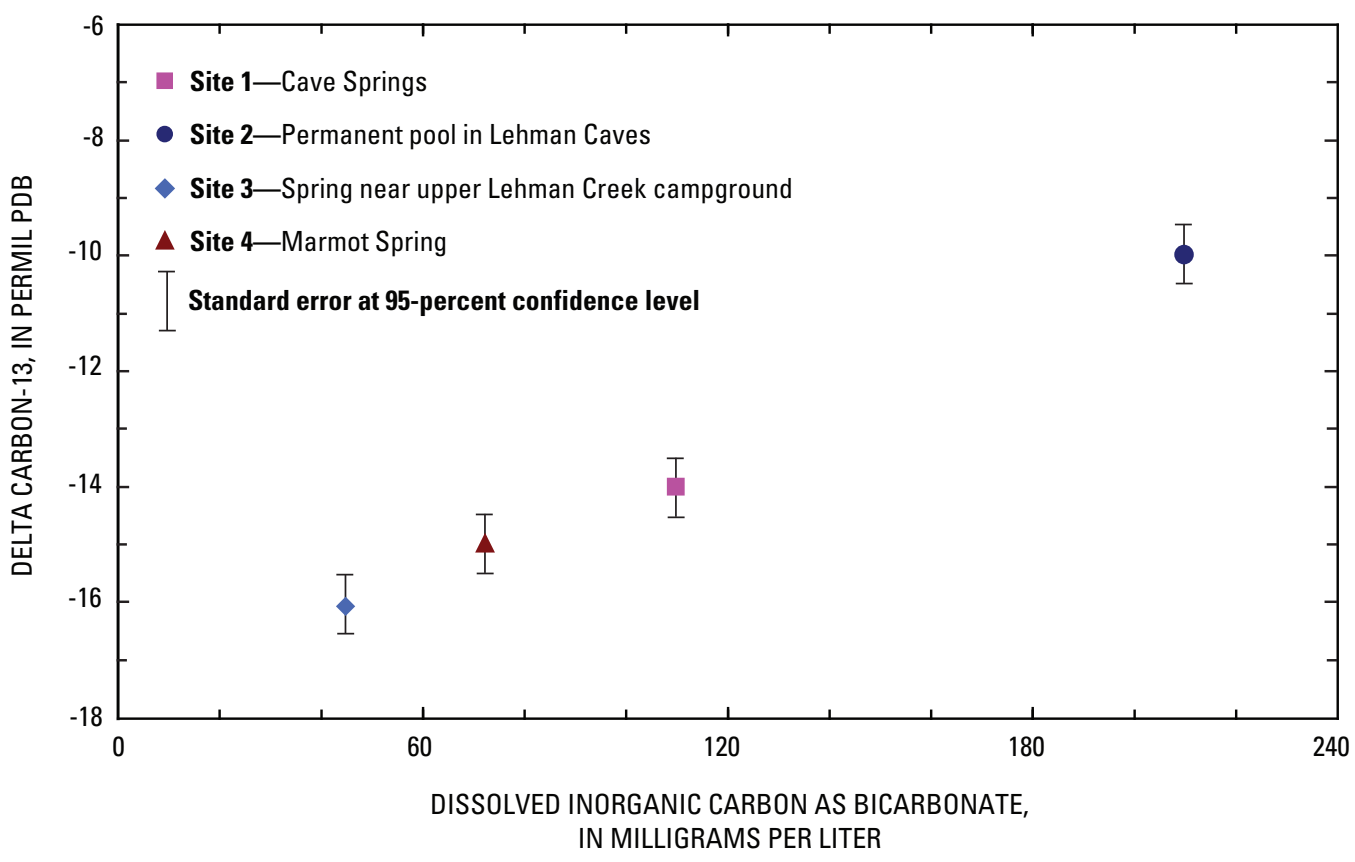

Figure 9. Relation between delta carbon-13 $\left(\delta^{13} \mathrm{C}\right)$ and dissolved inorganic carbon in water samples collected from Cave Springs, a permanent pool in Lehman Caves, and two nearby springs, Great Basin National Park, Nevada, September 2007. Site locations are shown in figure 2. 
inorganic carbon in water from the permanent pool in Lehman Caves are caused by dissolution of the Pole Canyon Limestone, which is nearly pure calcium carbonate (Lee and Van Loenen, 1971) and has a $\delta^{3} \mathrm{C}$ value of -0.82 permil PDB (table 6).

The dissolved-strontium concentration in water is least from Marmot Spring and the spring near upper Lehman Creek campground and greatest in the permanent pool at Lehman Caves (table 5; fig. 10). Strontium isotopes in water show a decrease in the ratio of ${ }^{87} \mathrm{Sr} /{ }^{86} \mathrm{Sr}$ from the spring near upper Lehman Creek campground to the pool in Lehman Caves (table 5; fig. 10). The ratio of ${ }^{87} \mathrm{Sr} /{ }^{86} \mathrm{Sr}$ in Pole Canyon Limestone associated with the pool in Lehman Caves is less than that of the ratio in the Prospect Mountain Quartzite at upper Lehman Creek campground or in the Tertiary granite near Cave Springs. Ratios of ${ }^{87} \mathrm{Sr} /{ }^{86} \mathrm{Sr}$ for Pole Canyon Limestone and Prospect Mountain Quartzite reported by Lee and others (1986, p. 173) are 0.70911 and 0.79620 , respectively, and are similar to those listed in table 6. One Tertiary granite sample near Marmot Spring had ${ }^{87} \mathrm{Sr} /{ }^{86} \mathrm{Sr}$ ratio of 0.7821 (Lee and others, 1986, p. 173), which is much higher than the value listed in table 6.

The strontium isotope ratio in water from the spring near upper Lehman Creek campground is consistent with dissolution of strontium from the quartzite. However, the strontium isotope ratio in water from the Marmot Spring is much less than water from Cave Springs and the spring near upper Lehman Creek campground. The reason for the difference is not known but could be caused by variations in the ratios of soluble strontium isotopes in the Prospect Mountain Quartzite or in the Tertiary granite through which ground water flows prior to discharging at Marmot Spring. Because the granite may have similar strontium isotope ratios as the quartzite, the ${ }^{87} \mathrm{Sr} /{ }^{86} \mathrm{Sr}$ ratio in water can best be used to determine if the water has been primarily in contact with carbonate or noncarbonate rocks in the study area but not between quartzite and granite. Another possibility is that water discharging from Marmot Spring may have come in contact with the Pioche Shale into which the granite intruded or the Pole Canyon Limestone. The possibility of Pole Canyon Limestone near the spring seems unlikely however, because dissolved-strontium concentration in the water is nearly the same as that from the spring near upper Lehman Creek campground and considerably less than that in water from Cave Springs (ig. 10).
Table 6. Stable isotopes of oxygen and carbon in rock sample of Pole Canyon Limestone and ratio of strontium isotopes and concentration of strontium in rock samples of Pole Canyon Limestone, Tertiary granite, and Prospect Mountain Quartzite near Cave Springs at Great Basin National Park, Nevada.

[Site locations are shown in figure 2. All rock samples were collected on September 8, 2007, between 7:45 and 9:30 AM Pacific Standard Time. Analyses were done by U.S. Geological Survey Yucca Mountain Project Environmental laboratory, Lakewood, Colorado. Symbol: -, not determined]

\begin{tabular}{cccc}
\hline $\begin{array}{c}\text { Stable isotope/ } \\
\text { constituent in rock }\end{array}$ & $\begin{array}{c}\text { Site 5 } \\
\text { Pole } \\
\text { Canyon } \\
\text { Limestone }\end{array}$ & $\begin{array}{c}\text { Site 6 } \\
\text { Tertiary } \\
\text { granite }\end{array}$ & $\begin{array}{c}\text { Site 7 } \\
\text { Prospect } \\
\text { Mountain } \\
\text { Quartzite }\end{array}$ \\
\hline $\begin{array}{c}\text { Oxygen-18/oxygen-16 }\left({ }^{18} \mathrm{O} /{ }^{16} \mathrm{O}\right) \\
\text { as } \delta^{18} \mathrm{O} \text { in permil VSMOW }\end{array}$ & 2.0 & - & - \\
$\begin{array}{c}\text { Oxygen-18/oxygen-16 }\left({ }^{18} \mathrm{O} /{ }^{16} \mathrm{O}\right) \\
\text { as } \delta^{18} \mathrm{O} \text { in permil PDB }\end{array}$ & -28.0 & - & - \\
$\begin{array}{c}\text { Carbon-13/carbon-12 }\left({ }^{13} \mathrm{C} /{ }^{12} \mathrm{C}\right) \\
\text { as } \delta^{13} \mathrm{C} \text { in permil PDB }\end{array}$ & -0.82 & - & - \\
$\begin{array}{c}\text { Strontium-87/strontium-86 } \\
\left({ }^{87} \mathrm{Sr} /{ }^{26} \mathrm{Sr}\right)^{3}\end{array}$ & 0.71358 & 0.72695 & 0.75487 \\
$\begin{array}{c}\text { Strontium (milligrams per } \\
\text { kilogram of rock) }\end{array}$ & 240 & 47 & 6.6 \\
\hline
\end{tabular}

${ }^{1}$ Ratio reported in delta $(\delta)$ notation as parts per thousand (permil). Delta is the relative difference between ratios of oxygen-18 to oxygen-16 $\left({ }^{18} \mathrm{O} /{ }^{16} \mathrm{O}\right)$ in sample of Pole Canyon Limestone to that in Vienna Standard Mean Ocean Water (VSMOW; Gonfiantini, 1978). A positive value represents a sample with more ${ }^{18} \mathrm{O}$ relative to ${ }^{16} \mathrm{O}$ than VSMOW. Standard error at 95 -percent confidence level is 0.2 permil.

${ }^{2}$ Ratios reported in delta $(\delta)$ notation as parts per thousand (permil). Delta is the relative difference between the ratios of oxygen-18 to oxygen-16 $\left({ }^{18} \mathrm{O} /{ }^{16} \mathrm{O}\right)$ and carbon-13 to carbon-12 $\left({ }^{13} \mathrm{C} /{ }^{12} \mathrm{C}\right)$ in sample of Pole Canyon Limestone to the respective ratio in a sample of belemnite from the Pee Dee Formation of South Carolina (PDB; Craig, 1957). Negative values of $\delta^{18} \mathrm{O}$ and $\delta^{13} \mathrm{C}$ represent samples with less ${ }^{18} \mathrm{O}$ and ${ }^{13} \mathrm{C}$ relative to ${ }^{16} \mathrm{O}$ and ${ }^{13} \mathrm{C}$ in the standard sample of PDB, respectively. Standard error at 95-percent confidence level is 0.2 permil for $\delta^{18} \mathrm{O}$ and 0.5 permil for $\delta^{13} \mathrm{C}$.

${ }^{3}$ Ratios are based on repetitive analyses on the seawater standard, EN-1. The error on the ratio of strontium- 87 to strontium- $86\left({ }^{87} \mathrm{Sr} /{ }^{86} \mathrm{Sr}\right)$ is \pm 0.00005 at the 95-percent confidence level. 


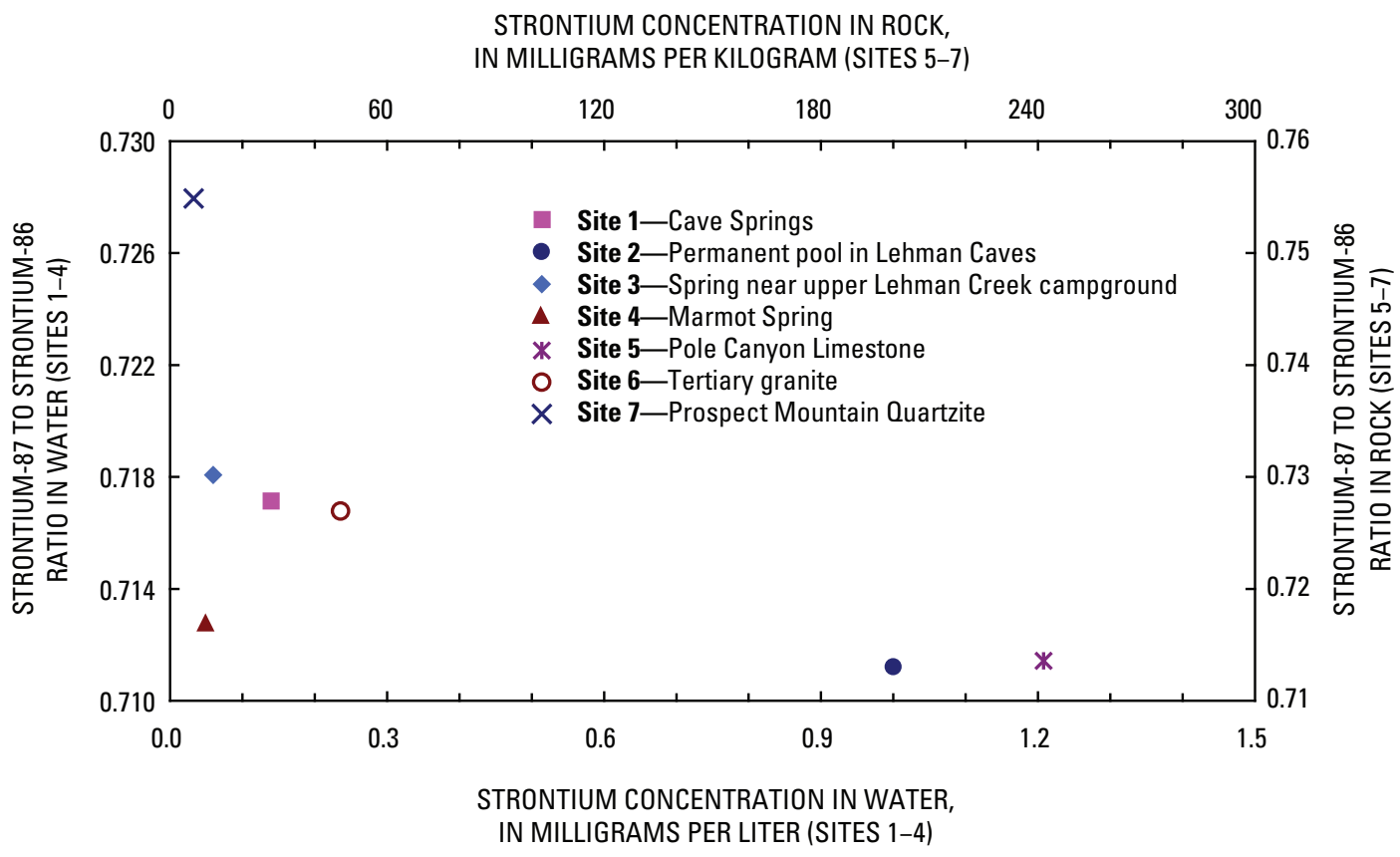

Figure 10. Relation between the ratio of strontium- 87 to strontium- 86 and strontium concentrations in water samples collected from Cave Springs, a permanent pool in Lehman Caves, and two nearby springs, and in rock samples of Pole Canyon Limestone, Tertiary granite, and Prospect Mountain Quartzite, Great Basin National Park, Nevada, September 2007. Site locations are shown in figure 2.

\section{Source of Calcium, Bicarbonate, and Strontium at Cave Springs}

No outcrop of Pole Canyon Limestone was found at or upstream of Cave Springs. Glacial deposits consisted of large boulders of quartzite upstream of the springs and a mixture of quartzite and granite at the springs. However, several pieces of rounded limestone gravel were removed during the hand deepening of a pool at the overflow outlet from the watercollection system. The 2-4 in. diameter limestone gravel was much smaller than the large boulders and cobbles strewn about the land surface upstream of the springs. Because the limestone gravel was rounded, it had to be transported a considerable distance by water yet there is no evidence of a limestone outcrop at or upstream of the springs.

Upon further inquiry as to the source of the rounded limestone gravel at Cave Springs, Craig Baker, a local rancher, recalled hauling many tons of gravel in 1996 during the reconstruction of water-collection system at Cave Springs.
The gravel was taken from a pit on the Baker ranch at the base of the alluvial fan on Lehman and Baker Creeks near Baker, Nevada (fig. 2), and contains rounded gravel of Prospect Mountain Quartzite, granite, and Pole Canyon Limestone. The gravel was used as filter material around each of the four principal springs and around the drain pipe.

A water sample from Cave Springs was collected July 22, 1987, prior to reconstruction (table 3; data from Gretchen Baker, National Park Service, Great Basin National Park, written commun., 2008) had a dissolved chemistry nearly identical to water from the Marmot Spring, although the $\mathrm{pH}$ at Cave Springs was 7.0 instead of 5.8 (table 3). The similarity in chemistry between water from Cave Springs prior to reconstruction and Marmot Spring indicates that the source of additional calcium, strontium, and bicarbonate in water sampled in September 2007 at Cave Springs is from the gravel placed around the four orifices during reconstruction of the water-collection system. 
The limestone gravel removed at the end of the overflow outlet pipe was pitted and etched indicating active dissolution of limestone and is consistent with the change in chemistry of Cave Springs between 1987 and 2007. Additionally, a small spring (discharging about $1 \mathrm{~L} / \mathrm{min}$ ) at the base of the Prospect Mountain Quartzite about $300 \mathrm{ft}$ west of Caves Springs had a specific conductance of $106 \mu \mathrm{S} / \mathrm{cm}$ at $25^{\circ} \mathrm{C}$ and a temperature of $11.6^{\circ} \mathrm{C}$ at the time that overflow from the Caves Springs collection system was sampled. These measurements are similar to those at Marmot Spring; therefore, Pole Canyon Limestone likely does not underlie the glacial deposits beneath Cave Springs as suggested by Elliott and others (2006, p. 32) and illustrated in figure $3 \mathrm{~A}$. Water likely discharges at or near the contact between Prospect Mountain Quartzite and the Tertiary granite that is covered by a thin veneer of glacial deposits (fig. 3B). Because the springs discharge from a thin veneer of glacial deposits at the upstream side of the contact between quartzite and granite, the potential for spring depletion from ground-water pumping in Spring Valley east of the park is less than if permeable carbonate rocks were present beneath the springs and connected with the thicker alluvial and glacial deposits along Lehman Creek drainage.

\section{Modeling Water Chemistry at Cave Springs}

The dissolved chemistry of water discharging from Cave Springs has changed since the water-collection system at Cave Springs was reconstructed in 1996. Because gravel containing Pole Canyon Limestone was used in the area of the four main springs that constitute most of the discharge at Cave Springs, the likely source of the increased concentrations of bicarbonate and calcium in the springs is the dissolution of the limestone gravel. The geochemical models PHREEQC and NETPATH (Parkhurst and Appelo, 1999 and Plummer and others, 1994, respectively) were used to determine if dissolution of limestone can explain the increase in bicarbonate and calcium in water at Cave Springs. The latest version NETPATHXL (Parkhurst and Charlton, 2008) was used in entering the geochemical data and in evaluating results from the NETPATH models.

Two geochemical models were tested. The first model used the major ion chemistry of the sample from Cave Springs collected in July 1987 prior to reconstruction of the watercollection system as the initial water and the chemistry of Cave Springs sample collected in September 2007 as the final water. Because dissolved strontium, $\mathrm{d}^{13} \mathrm{C}$, and ${ }^{87} \mathrm{Sr} /{ }^{86} \mathrm{Sr}$ were not analyzed for the sample collected prior to reconstruction of the water-collection system, values from the spring near upper
Lehman Creek campground (tables 3 and $\underline{5}$ ) were substituted instead. The second model used the water chemistry of the Marmot Spring as the initial water. Dissolved ions in Marmot Spring were nearly the same as that of Cave Springs before reconstruction (table 3 ) except the $\mathrm{pH}$ at Marmot Spring was more acidic.

The saturation index is used in NETPATH to determine if the dissolved chemistry of water is in equilibrium with a mineral (table 7). The saturation index is the log of the ratio of ion activity product (IAP) to the solubility product at the measured temperature $\left(\mathrm{K}_{\mathrm{t}}\right)$. Water is in equilibrium with a mineral when the saturation index is zero. The water is undersaturated with respect to a mineral when the value is less than zero and oversaturated with respect to a mineral when the value is greater than zero. Dissolved-oxygen concentrations were used for redox. The water from Marmot Spring and at Cave Springs before and after reconstruction of the watercollection system are all undersaturated with respect to the carbonate minerals (calcite, dolomite, siderite, rhodochrosite, and strontianite), sulfate minerals (gypsum and celestite), fluorite, and a few silicate minerals (potassium feldspar, albite, and anorthite) indicating the water could dissolve these minerals when present. All three samples are undersaturated with respect to the partial pressure of carbon dioxide gas. The carbonate minerals commonly are associated with limestone and the silicate minerals are associated with granitoid rocks such as the Tertiary granite. The water is saturated to oversaturated with respect kaolinite, manganese hydroxide (manganite), and iron oxide (goethite) indicating that these minerals could precipitate. Water from Cave Springs also is saturated to oversaturated with potassium mica, illite, and gibbsite (table 7).

The chemical composition of the three rock types are reported in Lee and Van Loenen (1971). The Pole Canyon Limestone is nearly pure calcite whereas the Prospect Mountain Quartzite in nearly pure silica dioxide (more than 90 percent by weight, respectively; Lee and Van Loenen, 1971, p. 36). The Tertiary granite west of Lehman Caves consists of quartz ( 35 percent), plagioclase ( 32 percent), microcline (23 percent), and muscovite ( 8 percent; Lee and Van Loenen, 1971, p. 42, sample 127). The plagioclase primarily is albite. Iron, manganese, and fluoride are present at low concentrations in all three rock types whereas chloride is below detection. Magnesium is most abundant in the Pole Canyon Limestone, but is only 2 percent by weight (Lee and Van Loenen, 1971, p. 36). Finally, strontium concentrations reported by Lee and Van Loenen are similar to those listed in table 6. 
Table 7. Saturation indexes for selected minerals and the partial pressure of carbon dioxide gas calculated from dissolved chemistry in water from Cave Springs prior to and after reconstruction of water-collection system and from Marmot Spring, Great Basin National Park, Nevada.

[Site locations are shown in figure 2. Concentration of dissolved oxygen was used for the Redox state. Saturation index: A measure of disequilibrium expressed as the $\log$ of the ratio of the ion activity product (IAP) divided by the solubility product at the measured water temperature ( $\mathrm{K}_{\mathrm{t}}$ ). A value of zero means the water is in equilibrium with a particular mineral. A value less than zero means the water is undersaturated with respect to a particular mineral and a value greater than zero means the water is oversaturated with respect to a particular mineral]

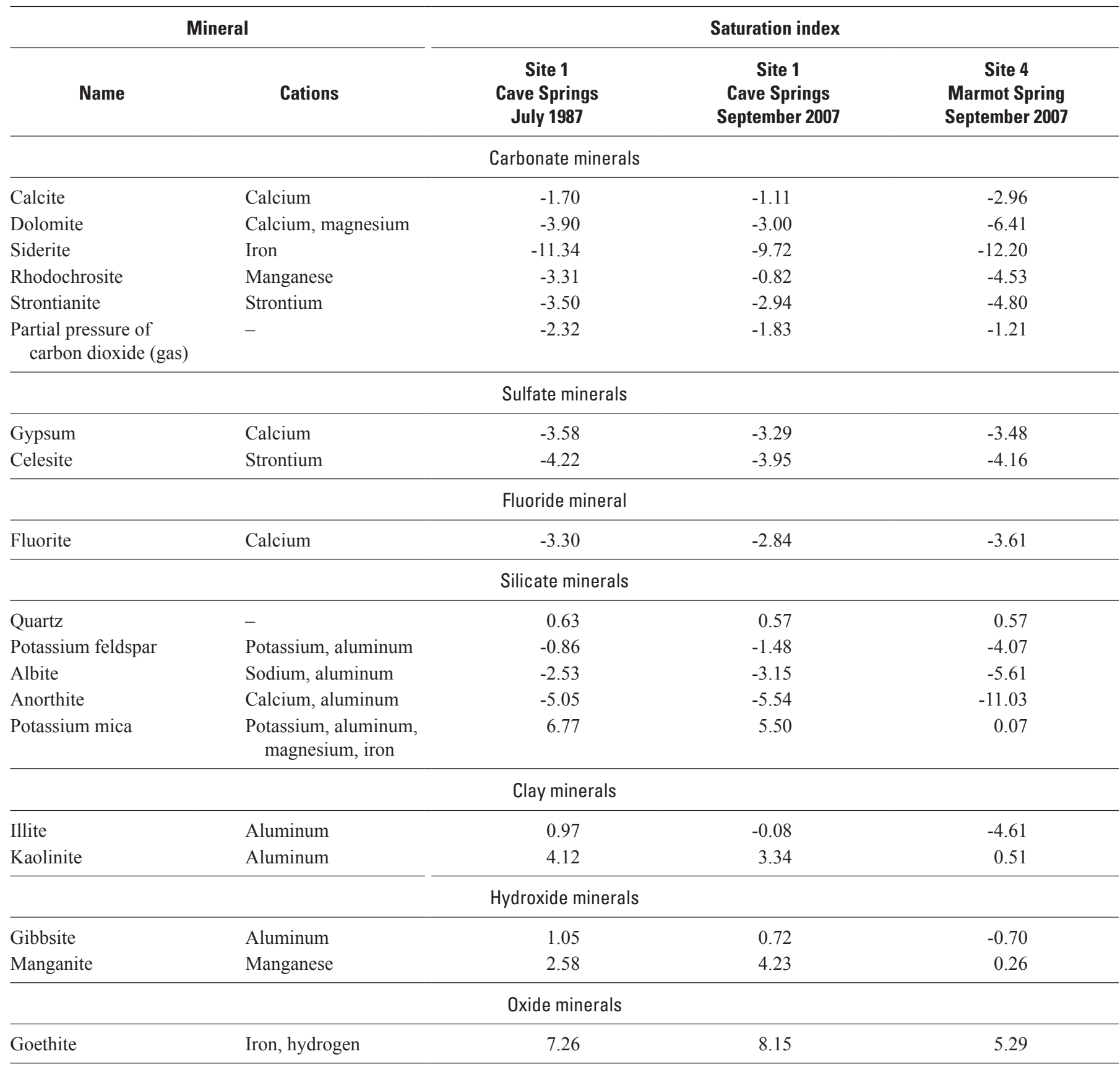


Many combinations of minerals can produce reasonable geochemical models. However, the models tested were limited to the dissolution of the various carbonate minerals likely associated with the Pole Canyon Limestone. Chemical precipitation was limited to iron sulfide and kaolinite. Carbon dioxide, soil organic matter (represented by $\mathrm{CH}_{2} \mathrm{O}$ ), and hydrogen sulfide gas were included as potential reactants in the model. Hydrogen sulfide was included in the models because the water at Cave Springs had the distinct smell of the gas while sampling. Phases considered in the models are listed in table 8 . The models were constrained by the mass balance of several ions, as well as $\delta^{13} \mathrm{C}$ and ${ }^{87} \mathrm{Sr} /{ }^{86} \mathrm{Sr}$. Values $\delta^{13} \mathrm{C}$ and ${ }^{87} \mathrm{Sr} /{ }^{86} \mathrm{Sr}$ ratio listed in table 6 were used in the analysis. Uncertainty for $\delta^{13} \mathrm{C}$ was assumed to be 1 permil, whereas the uncertainty of the ${ }^{87} \mathrm{Sr} /{ }^{86} \mathrm{Sr}$ ratio was assumed to be 0.007 . Although the limestone consists mostly of calcium carbonate, magnesium, strontium, iron, and manganese, can be substituted for calcium (Mason and Berry, 1968, p. 330-349). This analysis assumed the limestone consisted of calcite, dolomite (calcium and magnesium) and strontianite (strontium) that had the same $\delta^{13} \mathrm{C}$ composition.

When the initial water was Cave Springs, prior to reconstruction of the water-collection system, a reasonable result was found by dissolving carbonate minerals, carbon dioxide, and soil organic matter, precipitating kaolinite, and releasing a small amount of hydrogen sulfide gas $(0.001 \mathrm{mmol} / \mathrm{kg}$ of water; table 9$)$. The geochemical model was able to reproduce the value of $\mathrm{d}^{13} \mathrm{C}$ given an initial value of -16 permil determined from the spring near upper Lehman Creek campground. The model also reproduced the ${ }^{87} \mathrm{Sr} r{ }^{86} \mathrm{Sr}$ ratio of the final water by dissolving a small quantity of anorthite assuming the trace concentration of strontium in the granite (table 6) was associated with anorthite. The chemical equation for anorthite was modified in PHREEQC as:

$$
\begin{aligned}
\mathrm{Ca}_{0.995} \mathrm{Sr}_{0.005} \mathrm{Al}_{2} \mathrm{Si}_{2} \mathrm{O}_{8} & +8 \mathrm{H}_{2} \mathrm{O} \\
& =0.995 \mathrm{Ca}^{+2}+0.005 \mathrm{Sr}^{+2} \\
& +2 \mathrm{Al}(\mathrm{OH})_{4}^{-}+2 \mathrm{H}_{4} \mathrm{SiO}_{4} .
\end{aligned}
$$

The amount of anorthite dissolved was $0.14 \mathrm{mmol} / \mathrm{kg}$ of water and resulted in the chemical precipitation of slightly more kaolinite (table 9).

When the initial water was Marmot Spring, a reasonable result was determined by off gassing (evolving) carbon dioxide instead of dissolving it into water because of the low $\mathrm{pH}$ of 5.8 in the water (table 3). Results from the geochemical model using water from Marmot Spring are listed in table 10 and are similar to those when the initial water was Cave Springs prior to reconstruction of the water-collection system,
Table 8. Dissolved constituents and mineral and gas phases used to model geochemical reactions assuming initial waters from Cave Springs prior to reconstruction of water-collection system and Marmot Spring, and final water from Cave Springs after reconstruction, Great Basin National Park, Nevada.

[Dissolved constituents used in inverse model calculations: Concentration of dissolved oxygen was used for the Redox state. Dissolved strontium concentration, delta carbon-13, and strontium- 87 to strontium-86 ratio for Cave Springs sample collected in July 1987 prior to reconstruction of water collection system were assumed equal to values from spring near upper Lehman Creek campground. The concentration of dissolved oxygen, however, was assumed to be the same as that from Marmot Spring. Mineral and gas phases: Mineral and gas phases allowed to interact with the initial water to produce water discharging from Cave Springs in September 2007]

\begin{tabular}{l|l}
\hline $\begin{array}{c}\text { Dissolved constituents } \\
\text { used in inverse model } \\
\text { calculations }\end{array}$ & \multicolumn{1}{c}{\begin{tabular}{c}
\multicolumn{1}{c}{ Mineral and } \\
gas phases
\end{tabular}} \\
\hline Aluminum & \multicolumn{1}{c}{ Anorthite $\left[\mathrm{Ca}_{0.995} \mathrm{Sr}_{0.005} \mathrm{AL}_{2} \mathrm{Si}_{2} \mathrm{O}_{8}\right]$} \\
Calcium & Calcite $\left[\mathrm{CaCO}_{3}\right]$ \\
Carbon & Carbon dioxide gas $\left[\mathrm{CO}_{2}\right]$ \\
Chloride & Chalcedony $\left[\mathrm{SiO}_{2}\right]$ \\
Delta carbon-13 & Dolomite $\left.\left[\mathrm{CaMg} \mathrm{CO}_{3}\right)_{2}\right]$ \\
Magnesium & Goethite $[\mathrm{HFeO}]$ \\
Redox & Hydrogen sulfide gas $\left[\mathrm{H}_{2} \mathrm{~S}\right]$ \\
Silica & Iron sulfide $[\mathrm{FeS}]$ \\
Sodium & Kaolinite $\left[\mathrm{Al}_{4} \mathrm{Si}_{4} \mathrm{O}_{10}\left(\mathrm{OH}_{8}\right]\right.$ \\
Strontium & Sodium chloride $\left[\mathrm{NaCl}_{8}\right]$ \\
Strontium- 87 to & Soil organic matter $\left[\mathrm{CH} \mathrm{H}_{2} \mathrm{O}\right]$ \\
strontium- 86 ratio & \\
Sulfur & Strontianite $\left[\mathrm{SrCO}_{3}\right]$ \\
\hline
\end{tabular}

except carbon dioxide was off-gassed and no strontianite needed to be dissolved because of the already low ratio of ${ }^{87} \mathrm{Sr} /{ }^{86} \mathrm{Sr}$ ratio in the water at Marmot Spring. The measured ${ }^{87} \mathrm{Sr} /{ }^{86} \mathrm{Sr}$ ratio was obtained in the model by dissolving a small quantity of anorthite (about $0.1 \mathrm{mmol} / \mathrm{kg}$ of water) but the calculated value of $\delta^{13} \mathrm{C}$ was heavier than observed because of the off gassing of carbon dioxide.

The modeling results presented herein indicate that the increase in dissolved calcium, strontium, and bicarbonate measured in water sampled at Cave Springs in September 2007 can be explained by dissolution of limestone and granitoid rocks. Additionally, the dissolution is best explained by the placement of gravel containing rounded clasts of limestone during reconstruction of the watercollection system at the springs. 
Table 9. Results of geochemical modeling using NETPATH to evaluate dissolution of carbonate rocks at Cave Springs assuming initial water is water from Cave Springs prior to reconstruction of water-collection system, Great Basin National Park, Nevada.

[Dissolving phases: Mineral and gas phases used to produce water discharging from Cave Springs in September 2007; positive values are phases that add dissolved minerals to water at Cave Springs, whereas negative values are phases that remove dissolved minerals from water at Cave Springs. Delta carbon-13 and strontium-87 to strontium-86 ratio: Values for carbonate minerals are from analyses of Pole Canyon Limestone listed in table 6 and measured values in water from Cave Springs are listed in table 5 adjusted by PHREEQC on basis of rock uncertainty. Estimated uncertainty for delta carbon-13 in the limestone was 1 permil and in carbon dioxide gas and soil carbon was 2 permil. Estimated uncertainty for strontium- 87 to strontium- 86 ratio in rock was 0.007 . Magnesium in limestone assumed as dolomite. Strontium substitutes for calcium in the limestone but was assumed as separate mineral for the analysis (Mason and Berry, 1968, p. 331). Delta carbon-13 was assumed to be the same for all carbonate minerals. Values of delta carbon-13 and strontium-87 to strontium- 86 ratios used for the initial water at Cave Springs prior to reconstruction of water-collection system were from the spring near upper Lehman Creek campground. Abbreviations: -, not applicable; PDB, Pee Dee Formation of South Carolina]

\begin{tabular}{|c|c|c|c|}
\hline $\begin{array}{c}\text { Mineral } \\
\text { and } \\
\text { gas phases }\end{array}$ & $\begin{array}{l}\text { Dissolving phases, } \\
\text { in millimole per } \\
\text { kilogram of water }\end{array}$ & $\begin{array}{c}\text { Delta } \\
\text { carbon-13, } \\
\text { in permil } \\
\text { PDB }\end{array}$ & $\begin{array}{c}\text { Strontium-87 to } \\
\text { strontium-86 } \\
\text { ratio }\end{array}$ \\
\hline Anorthite & 0.141 & - & 0.719 \\
\hline Calcite & 0.363 & -0.82 & - \\
\hline Carbon dioxide gas & 0.990 & -15.2 & - \\
\hline Chalcedony & 0.00001 & - & - \\
\hline Dolomite & 0.0206 & -0.82 & - \\
\hline $\begin{array}{l}\text { Hydrogen sulfide } \\
\text { gas }\end{array}$ & 0.00000 & - & - \\
\hline Goethite & 0.00408 & - & - \\
\hline Iron sulfide & 0.00000 & - & - \\
\hline Kaolinite & -0.141 & - & - \\
\hline Sodium chloride & 0.00000 & - & - \\
\hline Soil organic matter & 0.162 & -25 & \\
\hline Strontianite & 0.00021 & -0.82 & 0.707 \\
\hline \multicolumn{4}{|c|}{ Isotopic composition } \\
\hline $\begin{array}{l}\text { Measured in final } \\
\text { water }\end{array}$ & - & -14.1 & 0.717 \\
\hline $\begin{array}{l}\text { Computed in final } \\
\text { water }\end{array}$ & - & -14 & 0.717 \\
\hline
\end{tabular}

Table 10. Results of geochemical modeling using NETPATH to evaluate dissolution of carbonate rocks at Cave Springs assuming initial water is water from Marmot Spring, Great Basin National Park, Nevada.

[Dissolving phases: Mineral and gas phases used to produce water discharging from Cave Springs in September 2007; positive values are phases that add dissolved minerals to water at Marmot Spring, whereas negative values are phases that remove dissolved minerals from water at Marmot Spring. Delta carbon-13 and strontium-87 to strontium-86 ratio: Values of delta carbon- 13 and strontium- 87 to strontium- 86 ratios for carbonate minerals are from analyses of Pole Canyon Limestone listed in table 6 and observed values in water from Cave Springs are listed in table 5 adjusted by PHREEQC on basis of rock uncertainty. Estimated uncertainty for delta carbon-13 in the limestone was 1 permil and in carbon dioxide gas and soil carbon was 2 permil. Estimated uncertainty for strontium- 87 to strontium- 86 ratio in rock was 0.007 . Magnesium in limestone assumed as dolomite. Strontium substitutes for calcium in the limestone but was assumed as separate mineral for the analysis (Mason and Berry, 1968, p. 331). Delta carbon-13 was assumed the same for all carbonate minerals. Abbreviations: -, not applicable; PDB, Pee Dee Formation of South Carolina]

\begin{tabular}{lccc}
\hline $\begin{array}{c}\text { Mineral } \\
\text { and } \\
\text { gas phases }\end{array}$ & $\begin{array}{c}\text { Dissolving phases, } \\
\text { in millimoles per } \\
\text { kilogram of water }\end{array}$ & $\begin{array}{c}\text { Delta } \\
\text { carbon-13, in } \\
\text { permil PDB }\end{array}$ & $\begin{array}{c}\text { Strontium-87 to } \\
\text { strontium-86 } \\
\text { ratio }\end{array}$ \\
\hline Anorthite & 0.209 & - & 0.719 \\
Calcite & 0.300 & -0.82 & - \\
Carbon dioxide gas & -1.99 & -15.9 & - \\
Chalcedony & -0.00001 & - & - \\
Dolomite & 0.0288 & -0.82 & - \\
Goethite & 0.211 & - & - \\
Hydrogen sulfide & -0.0125 & - & - \\
Iron sulfide & 0.00000 & - & - \\
Kaolinite & -0.209 & - & - \\
Sodium chloride & 0.00000 & - & - \\
Soil organic matter & 0.342 & -25 & 0.707 \\
Strontianite & -0.00002 & -0.82 & \\
\hline & Isotopic composition & \\
\hline Measured in final & - & -14.1 & 0.717 \\
$\quad$ water & & -11.3 & 0.717 \\
Computed in final & & & \\
water & & &
\end{tabular}




\section{Estimated Mean Age of Water at Four Sampling Sites}

Concentrations of chlorofluorocarbons dissolved in water collected from the four sampling sites were used to estimate the average age of ground water discharging from the springs and water in the permanent pool in Lehman Caves. Dissolvedgas concentrations were collected at the same time to estimate excess air, which is used in the calculation of the mean age of water from the chlorofluorocarbons. Concentrations of dissolved gases and chlorofluorocarbons at the four sampling sites are listed in table 11. Chlorofluorocarbons in water from the four sampling sites include a mixture of different chlorofluorocarbon concentrations from younger water and older water and thus only a mean age of ground water can be estimated.

Chlorofluorocarbon and dissolved-gas concentrations used to estimate the mean age of water can be affected by anoxic environments (absence of dissolved oxygen) where nitrogen-gas concentrations may be increased by denitrification and concentrations of chlorofluorocarbon decreased by degradation. Denitrification can result in an overestimate of recharge temperature and excess air that may affect the estimate of age. Additionally, anoxic environments result in the decomposition of chlorofluorocarbon that effectively will increase the estimate of age (Reston Chlorofluorocarbon Laboratory, U.S. Geological Survey, written commun., 2007). The first chlorofluorocarbon to degrade is CFC-11 followed by CFC-113 and then CFC-12 (Plummer and others, 1993). CFC-12 has proved to be the most reliable estimate of age. Only the sample for Cave Springs had low dissolved oxygen, a slight odor of hydrogen sulfide, and its water temperature was higher than the other three samples. Denitrification at Cave Springs could be occurring because total filtered nutrient nitrogen (table 4) was $0.12 \mathrm{mg} / \mathrm{L}$, which was about 0.3 and $0.4 \mathrm{mg} / \mathrm{L}$ less than that at Marmot Spring and the spring near upper Lehman Creek campground, respectively.

The temperature of water at the sampling sites and the average elevation of recharge were used in the calculation of the average recharge temperature and excess air. The recharge altitude for the pool in Lehman Caves is from percolation through Pole Canyon Limestone above the cave and thus,

Table 11. Concentrations of dissolved gases and chlorofluorocarbons in water collected from Cave Springs, a permanent pool in Lehman Caves, and two nearby springs, Great Basin National Park, Nevada.

[Site locations are shown in figure 2. Analyses were done by U.S. Geological Survey Chlorofluorocarbon Laboratory, Reston, Virginia. Sample dates and times are listed in tables 3 and 4 . Abbreviation:-, no value for third sample because only two samples analyzed]

\begin{tabular}{|c|c|c|c|c|}
\hline $\begin{array}{l}\text { Dissolved gas or } \\
\text { chlorofluorocarbon }\end{array}$ & $\begin{array}{c}\text { Site } 1 \\
\text { Cave Springs }\end{array}$ & $\begin{array}{c}\text { Site } 2 \\
\text { Pool in Lehman Caves }\end{array}$ & $\begin{array}{c}\text { Site } 3 \\
\text { Spring near upper Lehman } \\
\text { Creek campground }\end{array}$ & $\begin{array}{c}\text { Site } 4 \\
\text { Marmot Spring }\end{array}$ \\
\hline Number of samples analyzed & 2 & 2 & 2 & 2 \\
\hline Nitrogen $\left(\mathrm{N}_{2}\right)$ & $\begin{array}{l}13.8 \\
13.7\end{array}$ & $\begin{array}{l}13.7 \\
13.7\end{array}$ & $\begin{array}{l}15.2 \\
15.1\end{array}$ & $\begin{array}{l}14.2 \\
14.2\end{array}$ \\
\hline Oxygen $\left(\mathrm{O}_{2}\right)$ & $\begin{array}{l}0.475 \\
0.772\end{array}$ & $\begin{array}{l}4.01 \\
3.83\end{array}$ & $\begin{array}{l}5.43 \\
6.38\end{array}$ & $\begin{array}{l}3.32 \\
0.627\end{array}$ \\
\hline Carbon dioxide $\left(\mathrm{CO}_{2}\right)$ & $\begin{array}{l}13.6 \\
11.4\end{array}$ & $\begin{array}{l}7.57 \\
7.74\end{array}$ & $\begin{array}{l}13.8 \\
13.0\end{array}$ & $\begin{array}{l}19.2 \\
21.7\end{array}$ \\
\hline Number of samples analyzed & 3 & 3 & 2 & 2 \\
\hline CFC-11 & $\begin{array}{l}270 \\
268 \\
318\end{array}$ & $\begin{array}{r}1270 \\
814 \\
743\end{array}$ & $\begin{array}{r}621 \\
612 \\
-\end{array}$ & $\begin{array}{r}454 \\
445 \\
-\end{array}$ \\
\hline CFC-12 & $\begin{array}{l}167 \\
155 \\
148\end{array}$ & $\begin{array}{l}261 \\
265 \\
257\end{array}$ & $\begin{array}{r}315 \\
313 \\
-\end{array}$ & $\begin{array}{r}240 \\
244 \\
-\end{array}$ \\
\hline CFC-113 & $\begin{array}{l}34.1 \\
28.5 \\
25.5\end{array}$ & $\begin{array}{l}62.2 \\
62.4 \\
63.0\end{array}$ & $\begin{array}{c}86.8 \\
87.5 \\
-\end{array}$ & $\begin{array}{c}59.6 \\
60.3 \\
-\end{array}$ \\
\hline
\end{tabular}


the estimated elevation of the pool of $6,800 \mathrm{ft}$ was used as the recharge elevation. The cold temperature $\left(5.6^{\circ} \mathrm{C}\right)$ of the water discharging from the spring near upper Lehman Creek campground (site 3; table 3) indicates that the average recharge altitude is higher than that of the spring. The mean annual air temperature at the spring was estimated to be about $6.4^{\circ} \mathrm{C}$ on the basis of the 30 -year mean annual temperature of $8.6^{\circ} \mathrm{C}$ at Lehman Caves Visitor Center (Elliott and others, 2006), an increase in land-surface elevation of 1,090 ft between the spring and the visitors' center (table 1), and a temperature lapse rate of $-2^{\circ} \mathrm{C}$ per $1,000 \mathrm{ft}$ similar to that in the Wasatch Range near Salt Lake City, Utah (Hely and others, 1971). Discharge from this spring likely originates from recharge to alluvial and glacial deposits at the base of the north slope of Wheeler Peak where the temperature of the water remains cold because of shallow and relatively rapid groundwater flow through coarse alluvial and glacial deposits (fig. 2). The average altitude of the alluvial and glacial deposits was estimated to be $9,500 \mathrm{ft}$.
Water discharging from Cave Springs and from the Marmot Spring likely originates from precipitation on the east slope of Jeff Davis Peak (fig. 2). Water discharging from Cave Springs and Marmot Spring had warmer temperatures $\left(12.6^{\circ} \mathrm{C}\right.$ and $10.6^{\circ} \mathrm{C}$, respectively; table 3 ) than the spring near upper Lehman Creek campground indicating one or more of the following: a lower altitude of recharge; a deeper depth of ground-water flow; or a longer residence time of ground water. An average altitude of recharge is unknown but the springs are at an altitude of about 7,300 ft (table 1) and Jeff Davis Peak is more than 12,000 ft. Because much of the highest elevation around Jeff Davis Peak drains north to Lehman Creek and south to Baker Creek, the average recharge altitude was estimated at 9,000 $\mathrm{ft}$ and resulted in an average recharge temperature of $6.2^{\circ} \mathrm{C}$ for Marmot Spring and $8.4^{\circ} \mathrm{C}$ for Cave Springs (table 12).

Table 12. Estimated recharge temperatures from dissolved gases and range in age from chlorofluorocarbon analyses of water sampled from Cave Springs, a permanent pool in Lehman Caves, and two nearby springs, Great Basin National Park, Nevada.

[Site locations are shown in figure 2. Analyses were done by U.S. Geological Survey Chlorofluorocarbon Laboratory Reston, Virginia. Abbreviation: CFC, chlorofluorocarbon. Symbol: $<$, less than]

\begin{tabular}{|c|c|c|c|c|}
\hline $\begin{array}{l}\text { Dissolved gas or } \\
\text { chlorofluorocarbon }\end{array}$ & $\begin{array}{c}\text { Site } 1 \\
\text { Cave Springs }\end{array}$ & $\begin{array}{c}\text { Site } 2 \\
\text { Pool in Lehman Caves }\end{array}$ & $\begin{array}{c}\text { Site } 3 \\
\text { Spring near upper Lehman } \\
\text { Creek campground }\end{array}$ & $\begin{array}{c}\text { Site } 4 \\
\text { Marmot Spring }\end{array}$ \\
\hline \multicolumn{5}{|c|}{ Estimated recharge temperature and excess air from dissolved gases } \\
\hline Number of samples analyzed & 2 & 2 & 2 & 2 \\
\hline $\begin{array}{l}\text { Assumed recharge altitude, in feet above } \\
\text { mean sea level }{ }^{1}\end{array}$ & 9,000 & 6,800 & 9,500 & 9,000 \\
\hline Recharge temperature, in degrees Celsius ${ }^{2}$ & 8.4 & 10.8 & 3.2 & 6.2 \\
\hline $\begin{array}{l}\text { Excess air, in cubic centimeters at } \\
\text { standard temperature and pressure per } \\
\text { liter of water }{ }^{2}\end{array}$ & 0.2 & 0.0 & 0.3 & 0.0 \\
\hline
\end{tabular}

Estimated range in age of water

\begin{tabular}{lcccc}
\hline Estimated mean age in years $^{3}$ & & & & \\
CFC-11 & $31-33$ & Contaminated & 24 & 27 \\
CFC-12 & $27-30$ & $<15$ & 19 & $21-22$ \\
CFC-113 & $24-27$ & $<19$ & 19 & 21 \\
Estimated year of recharge $^{4}$ & $1977-83$ & After 1990 & 1988 & $1985-86$
\end{tabular}

\footnotetext{
${ }^{1}$ Assumed recharge altitude for sites 1 and 4 are based on average land-surface elevation in drainage and site 3 estimated from average land-surface elevation of glacial deposits. A change in the estimate of recharge altitude of 1,000 feet resulted in an uncertainty in the average age of water of 0.5 year for sites 1 and 4 , 1 year for site 3 , and several years for site 2 .

${ }^{2}$ Estimated temperature and excess air estimated from dissolved gas concentrations of nitrogen and argon, and assumed recharge altitude. Recharge temperature estimated by iteration until excess air computed from nitrogen and argon concentrations are the same. Increasing the recharge altitude 1,000 feet decreased the recharge temperature by about 1 degree Celsius and increased the excess air by about 0.05 cubic centimeter per liter at standard temperature and pressure. Decreasing the recharge altitude 1,000 feet increased the recharge temperature and decreased the excess air by a corresponding value.

${ }^{3}$ Estimated mean age of water was computed using estimates of recharge altitude, temperature, and excess air and assuming piston flow.

${ }^{4}$ Estimated year of recharge is based on mean age of water using CFC-12 and CFC-113. Water at Cave Springs (site 1) may be less than listed because of potential degradation caused by low dissolved oxygen concentrations; however, the mean age estimated from CFC-12 is older than that from CFC-113 and if degradation was a problem, the mean age of CFC-113 would be older because it degrades more rapidly than CFC-12.
} 
A possible explanation of the warmer recharge temperature for Cave Springs is thermal and gas re-equilibration within the buried water-collection system. The water sample collected at Cave Springs was from an overflow pipe in the water-collection system. The water-collection system is buried several feet beneath the land surface, so the amount of thermal heating and mixing that occurs with the atmosphere prior to where water was sampled is unknown. The increase in temperature likely is small because the temperature of a seep at the base of the outcrop of Prospect Mountain quartzite about $300 \mathrm{ft}$ west of Cave Springs was $11.6^{\circ} \mathrm{C}$ at the time when water was sampled from Cave Springs. Assuming a recharge temperature for Cave Springs is the same as Marmot Spring $\left(6.2^{\circ} \mathrm{C}\right)$, the mean age of water listed in table 12 increases by 1 year.

Although the estimate of the average recharge altitude is uncertain for the three springs, the uncertainty results in a small change in the estimated mean age of water. Increasing the recharge altitude by 1,000 $\mathrm{ft}$ for Cave Springs and Marmot Spring causes a decrease in the estimated recharge temperature of about $1{ }^{\circ} \mathrm{C}$, an increase in excess air of about $0.05 \mathrm{~cm}^{3} / \mathrm{L}$, and an increase in the mean age of $0.5 \mathrm{yr}$; whereas, decreasing the recharge altitude by $1,000 \mathrm{ft}$ causes a similar increase in recharge temperature, decrease in excess air, and a decrease in the mean age. Changing the recharge altitude of the pool in Lehman Caves by $+100 \mathrm{ft}$, causes a larger change in the range of estimated mean age because of the lack of sensitivity in using chlorofluorocarbon concentrations after 1990 (table 12). Water is added to the pool in Lehman Caves each spring from percolation through the Pole Canyon Limestone above the cave. Water in the caves was expected to have CFC concentrations consistent with current $\mathrm{CFC}$ concentrations in the atmosphere because water infiltrates through the soil and rock above the caves and drips from the cave roof into the pool.

Water discharging at Cave Springs had the oldest mean age of the four sampling sites followed by the spring near Baker Creek campground, the spring near upper Lehman Creek campground, and finally the youngest water was in the pool at Lehman Caves. Degradation of CFC at Cave Springs is only possible if CFC-12 degraded more than CFC-113, which is inconsistent with typical degradation of $\mathrm{CFC}-113$ then CFC-12 (Plummer and others, 1993). Sampling Cave Springs between late winter and early spring might result in a younger estimate of mean age of water at the springs because of local recharge from snowmelt near the springs.

\section{Summary and Conclusions}

Cave Springs are the water supply for the Lehman Caves Visitor Center at Great Basin National Park, which is about 60 miles east of Ely, Nevada, in White Pine County. Cave Springs were investigated to determine if ground water discharging at the springs could be shallow ground water moving through alluvial and glacial deposits associated with nearby Lehman Creek, through the quartzite, through limestone, or some combination of these rocks and deposits. Knowing the source of water to Cave Springs is important in evaluating its potential for depletion caused by ground-water pumping as well as to protect the supply from contamination.

Cave Springs consist of several small springs that discharge from alluvial and glacial deposits near the contact between quartzite and granite. The four largest springs are diverted into a water-collection system. Water from the collection system at Cave Springs had more dissolved strontium, calcium, and bicarbonate, and was heavier in the stable isotope of carbon-13, which is denoted as delta carbon- 13 or $\delta^{13} \mathrm{C}$, than water from the spring at the contact between quartzite and granite near Baker Creek campground indicating that water at Cave Springs had dissolved limestone prior to discharging. The source of the limestone at Cave Springs was determined to be rounded gravels from a pit near Baker, Nevada, which was placed around the springs during the reconstruction of the water-collection system in 1996. A water sample from Cave Springs collected July 1987 had similar dissolved concentrations of calcium, magnesium, and bicarbonate as the water sampled in September 2007 from Marmot Spring indicating a similar source prior to reconstruction of the water-collection system. A geochemical model using the water chemistry prior to reconstruction resulted in a plausible reaction model involving the dissolution of calcite and dolomite to produce the water chemistry at Cave Springs in September 2007.

Stable isotopes of hydrogen $(\delta \mathrm{D})$ and oxygen $\left(\delta^{18} \mathrm{O}\right)$ were lightest (most negative values) at Cave Springs and Marmot Spring and heaviest (least negative values) at a permanent pool in Lehman Caves. Comparison of stable isotopes in water at Cave Springs with winter and summer precipitation indicates that the source of water is primarily from winter precipitation. Mixing of water at Cave Springs from alluvial and glacial deposits along Lehman Creek with water from quartzite as represented by Marmot Spring is unlikely because $\delta \mathrm{D}$ and $\delta^{18} \mathrm{O}$ values from the spring near upper Lehman Creek campground is heavier than those at Cave Springs and Marmot Spring. Additionally, the estimated mean age of water from dissolved chlorofluorocarbon concentrations indicates water discharging from the alluvial and glacial deposits is younger than that discharging from either Cave Springs or Marmot Spring.

Because Cave Springs discharges from alluvial and glacial deposits at the upstream side of the contact between quartzite and granite, the potential for spring depletion from ground-water pumping in Snake Valley is less than if carbonate rocks were present beneath the springs providing a better connection with alluvial aquifers in the valley. Finally, the present protective fence enclosure around Cave Springs is sufficient because most of the source area to the springs is from the steep eastern slope of Jeff Davis Peak and not from alluvial and glacial deposits west of the springs. 


\section{Acknowledgments}

The National Park Service, Water Rights Branch, in Fort Collins, Colorado, funded the study. William Van Liew (National Park Service, Fort Collins, Colorado) assisted in the design. Gretchen Baker (National Park Service, Great Basin National Park, Baker, Nevada) provided guidance on all the necessary forms needed to sample water from Lehman Caves and the three springs, escorted us into and out of Lehman Caves and assisted in the collection of the water sample in the cave. Mrs. Baker also provided written information on the reconstruction of the water-collection system of Cave Springs and on historical chemical and stable isotope analyses of samples from Cave Springs, and ascertained the origin of the limestone gravel at Cave Springs.

\section{References Cited}

Acheampong, S.Y., 1992, Isotope hydrology of Lehman and Baker Creek drainages, Great Basin National Park, Nevada: Las Vegas, University of Nevada, Department of Geoscience, M.S. Thesis, 105 p.

Clark, I.D., and Fritz, Peter, 1997, Environmental isotopes in hydrogeology: New York, Lewis Publishers, 328 p.

Craig, Harmon, 1957, Isotopic standards for carbon and oxygen and correction factors for mass-spectrometric analysis of carbon dioxide: Geochimica et Cosmochimica Acta, v. 12, iss. 1-2, p. 133-149.

Craig, Harmon, 1961, Isotopic variations in meteoric water: Science, v. 133 , no. 3465 , p. 1702-1703.

Elliott, P.E., Beck, D.A., and Prudic, D.E., 2006, Characterization of surface-water resources in the Great Basin National Park and their susceptibility to groundwater withdrawals in adjacent valleys, White Pine County, Nevada: U.S. Geological Survey Scientific Investigations Report 2006-5099, 156 p.

Feth, J.H., Rogers, S.M., and Roberson, C.E., 1964, Chemical composition of snow in the northern Sierra Nevada and other areas: U.S. Geological Survey Water Supply Paper 1535-J, 39 p.

Friedman, Irving, Smith, G.I., Johnson, C.A., and Moscati, R.J., 2002, Stable isotope compositions of waters in the Great Basin, United States, 2. Modern precipitation: Journal of Geophysical Research, v. 107, no. D19, 4401, doi:10.1029/2001JD000566, p. ACL 15-1-15-2.

Giofiantini, R., 1978, Standards for stable isotope measurements in natural compounds: Nature, v. 271, no. 5645 , p. 534-536.
Hely, A.G., Mower, R.W., and Harr, C.A., 1971, Water resources of Salt Lake County, Utah: Utah Department of Natural Resources Technical Publication no. 31, 244 p.

Hem, J.D., 1985, Study and interpretation of the chemical characteristics of Natural Water ( $3^{\text {rd }}$ ed.): U.S. Geological Survey Water Supply Paper 2254, 263 p.

Hose, R.K., and Blake, M.C., Jr., 1976, Geology and mineral resources of White Pine County, Nevada, Part I, Geology: Nevada Bureau of Mines and Geology Bulletin 85, 105 p.

Lee, D.E., Kistler, R.W., and Robinson, A.C., 1986, The strontium isotope composition of granitoid rocks of the southern Snake Range, Nevada, in Peterman, Z.E., and Schnabel, D.C., eds., Shorter contributions to isotope research: U.S. Geological Survey Bulletin 1622, p. 171-179.

Lee, D.E., and Van Loenen, R.E., 1971, Hybrid granitoid rocks of the southern Snake Range, Nevada: U.S. Geological Survey Professional Paper 668, 48 p.

Maloney, T.J., ed., 2005, Quality management system, U.S. Geological Survey National Water Quality Laboratory: U.S. Geological Survey Open-File Report 3005-1263, ver. 1.3, variously paged (93 p. total).

Mason, Brian, and Berry, L.G., 1968, Elements of mineralogy: San Francisco, W.H. Freeman and Co., 550 p.

Miller, E.L., Gans, P.B., Grier, S.P., and Brown, J.L., compilers, 1995a, Geologic map of Windy Peak 7.5' quadrangle, White Pine County, Nevada: U.S. Geological Survey Open-File Report 94-687, scale 1:24,000.

Miller, E.L., Grier, S.P., and Brown, J.L., compilers, 1995b, Geologic map of the Lehman Caves quadrangle, White Pine County, Nevada: U.S. Geological Survey Geologic Quadrangle Map 1758, scale 1:24,000.

Miller, E.L., and the Stanford Geological Survey, 2007 (mapping 1993-1997), Geologic map of Great Basin National Park and environs, Southern Snake Range, Nevada: Palo Alto, Calif., Stanford Geological Survey, scale $1: 24,000$.

National Park Service, 2009, Digital geologic map of Great Basin National Park and vicinity, Nevada: National Park Service, accessed February 3, 2009, at http://science.nature. nps.gov/nrdata/datastore.cfm? ID $=44849$

Paces, J.B., Peterman, Z.E., Futo, Kiyoto, Oliver, T.A., and Marshall, B.D., 2007, Strontium isotopic composition of Paleozoic carbonate rocks in the Nevada Test Site vicinity, Clark, Lincoln, and Nye Counties, Nevada, Inyo County, California: U.S. Geological Survey Data Series 280, 42 p. 
Parkhurst, D.L., 1995, Users guide to PHREEQC-A computer program for speciation, reaction-path, advectivetransport, and inverse geochemical calculations: U.S. Geological Survey Water-Resources Investigations Report 95-4227, $143 \mathrm{p}$.

Parkhurst, D.L., and Appelo, C.A.J., 1999, Users guide to PHREEQC (version 2)-A computer program for speciation, batch-reaction, one-dimensional transport, and inverse geochemical calculations: U.S. Geological Survey Water-Resources Investigations Report 99-4259, 312 p.

Parkhurst, D.L., and Charlton, S.R., 2008, NetpathXL-An Excel $^{\circledR}$ interface to the program NETPATH: U.S. Geological Survey Techniques and Methods 6-A26, $11 \mathrm{p}$.
Pirkey, K.D., and Glodt, S.R., 1998, Quality control at the U.S. Geological Survey, National Water Quality Laboratory: U.S. Geological Survey Fact Sheet 98-026, 4 p.

Plummer, L.N., Michel, R.L., Thurman, E.M., and Glynn, P.D., 1993, Environmental tracers for age-dating young ground water, in Alley, W.M., ed., Regional ground-water quality: New York, Van Nostrand Reinhold, p. 255-294.

Plummer, L.N., Prestemon, E.C., and Parkhurst, D.L., 1994, An interactive code (NETPATH) for modeling NET geochemical reactions along a flow PATH, version 2.0: U.S. Geological Survey Water-Resources Investigations Report 94-4169, 130 p. 
Publishing support provided by the U.S. Geological Survey

Publishing Network, Tacoma Publishing Service Center

For more information concerning the research in this report, contact the Director, Nevada Water Science Center

U.S. Geological Survey

2730 N. Deer Run Road

Carson City, Nevada 89701

http://nevada.usgs.gov/water/ 


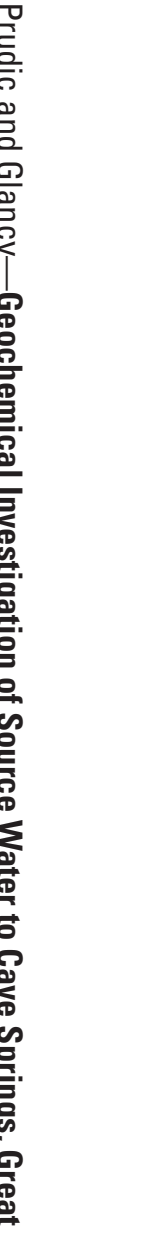

$\stackrel{心}{\Xi}$ 